\title{
Impact of Uncertainty and Sunk Costs on Firm Survival and Industry Dynamics
}

\author{
Vivek Ghosal* \\ School of Economics \\ Georgia Institute of Technology \\ Atlanta, GA 30332 \\ Vivek.Ghosal@econ.gatech.edu
}

January 2002

\begin{abstract}
In theory, uncertainty and sunk costs can influence industry dynamics through the option value and financing constraints channels. Empirical evaluation of these models in the context of industry dynamics are, however, at a nascent stage. Our empirical analysis, covering 267 U.S. manufacturing industries over a 30-year period, reveals that greater uncertainty (i) decreases the number of small firms and establishments in high sunk cost industries, (ii) has virtually no impact on larger establishments, (iii) results in a less skewed size distribution of firms and establishments in high sunk cost industries and (iv) marginally increases industry output concentration. Addressing the recent literature, we also control for technological change and our estimates show that technical progress decreases the number of small firms and establishments in an industry. While past studies have emphasized technological change as a key driver of industry dynamics, our results indicate that uncertainty and sunk costs play a crucial role. Our findings could be useful for the study of firm survival, models of creative destruction, evolution of firm size distribution, mergers and acquisitions and competition policy.

JEL: L11, D80, O30, G10, L40.

Keywords: Uncertainty, sunk costs, technological change, industry dynamics, firm size distribution, creative destruction, option value, financing constraints.
\end{abstract}

* For helpful comments and discussions, I thank Bob Chirinko, Andrew Dick, Ciaran Driver, Michael Funke, Boyan Jovanovic, Steven Klepper, Alex Raskovich, Dave Reitman, Mark Roberts, Mary Sullivan and seminar participants at the conference on "New Perspectives on Fixed Investment" organized by the Center for Mathematical Trading and Finance, City University of London Business School (2001), North American Econometric Society meetings (Maryland, 2001), European Network on Industrial Policy meetings (Vienna, 2001), Queens College, Georgia Institute of Technology, Tilburg University (Netherlands), New York University and University of Florida. 


\section{Introduction}

Several stylized facts appear well established: ${ }^{1}$ (i) there is significant churning of firms even in mature industries; (ii) entrants are typically small compared to incumbents and have low survival probabilities; (iii) typical exiting firm is small and young; and (iv) larger firms tend to be older with higher survival probabilities. Given these findings, identifying the forces that drive industry dynamics and the evolution of firm size distribution has taken on renewed interest. The relatively recent literature has tended to focus on technological change as the key driving force. ${ }^{2}$ The primary objective of this paper is to assess the role played by uncertainty and sunk costs on the intertemporal dynamics of industry structure.

Uncertainty and sunk costs imply an option value of waiting which alters the entry and exit trigger prices (Dixit, 1989; Dixit and Pindyck, 1994; Caballero and Pindyck, 1996). This suggests that the option value channel may be an important determinant of entry, exit and industry dynamics (Section II(i)). ${ }^{3} \mathrm{~A}$ second channel via which uncertainty and sunk costs may affect industry dynamics is financial market frictions (e.g., Greenwald and Stiglitz, 1990; Williamson, 1988; Cooley and Quadrini, 2000; Cabral and Mata, 2001). This literature suggests that uncertainty and sunk costs exacerbate financing constraints, affecting decisions of entrants and incumbents (Section II(ii)). Our study is motivated by the fact that while the theory linking uncertainty and sunk costs to industry dynamics is relatively well developed, empirical evaluation of these models appears limited. Finally, since the literature has shown innovation to be a key determinant of industry dynamics, our empirical analysis also examines the role played by technological change (Section III).

We assemble an extensive database covering 267 U.S. manufacturing industries over a 30-year period and containing information on the number of firms and establishments (by size class), output concentration, alternate proxies for sunk capital costs, and use time-series data to measure uncertainty and technical change (Section IV). A dynamic panel data model is used to estimate the impact of uncertainty and sunk costs on the intertemporal dynamics of various industry structure characteristics (Section V). Our key findings (Section VI) are that greater uncertainty (i) reduces the number of small establishments and firms primarily in high sunk cost industries; (ii) has virtually no impact on large establishments; (iii) results

\footnotetext{
${ }^{1}$ See Audretsch (1995), Caves (1998), Dunne, et al. (1988), Evans (1987), Geroski (1995) and Sutton (1997.a).

${ }^{2}$ See Agarwal and Gort (1996, 1999), Audretsch (1995), Caves (1998), Jovanovic and MacDonald (1994), Klepper (1999), Klepper and Simons (2000) and Sutton (1997.a; 1997.b).

${ }^{3}$ On the "churning" of firms, Sutton (1997.a; p.52-54) writes that fluctuations in industry profits influence entry and exit, and (p.53) "a new attack on this problem has been emerging recently, following the work of Avinash Dixit and Robert Pindyck (1994) on investment under uncertainty. Here, the focus is on analyzing the different thresholds associated with entry decisions which involve sunk costs and decisions to exit..." He goes on to note that empirical implementation lags theoretical advances.
} 
in a less skewed size distribution of firms and establishments in high sunk costs industries, and (iv) marginally increases industry concentration. Second, technological progress has an adverse impact on the number of small establishments and firms in an industry. Third, our estimates suggest that uncertainty and sunk costs have a greater quantitative impact on industry dynamics than technical change.

Our findings on uncertainty and sunk costs could be useful in several areas. First, they provide guidance for competition policy since analysis of entry and other forces that regulate competition are an integral part of DOJ and FTC merger guidelines. The guidelines contain extensive discussion of sunk costs as a barrier to entry, but uncertainty is de-emphasized. Our results suggest that uncertainty compounds the sunk cost barriers, lowers the probability of survival of smaller incumbents and retards entry. This implies that mergers, for example, ought to receive closer scrutiny in markets with greater uncertainty. Second, evaluating the determinants of merger and acquisition activity has long been an important area of research; see Jovanovic and Rousseau (2001) and the reference there. If uncertainty reduces the probability of survival, it would have implications for reallocation of capital; e.g., do the assets exit the industry or are they reallocated to other firms within the industry via merger or acquisition? Given our broad findings, it would be interesting to explore whether uncertainty in combination with sunk costs helps explain part of M\&A waves. Third, while skewed firm size distribution has been well documented, empirical analysis quantifying it's evolution is somewhat limited. Our results suggest that uncertainty and sunk costs are important determinants of the evolution of firm size distribution. Fourth, Davis, Haltiwanger and Schuh (1996) find that job destruction and creation decline sharply with firm size/age; Cooley and Quadrini (2000) shed more light on this and show that small/young firms have greater exits (destruction) due to financial market frictions. Our results provide specific insights: uncertainty and sunk costs significantly contribute to the turnover of firms. If entry and exit reflect the bigger picture of economic activity, then our results imply that uncertainty and sunk costs influence key variables like job turnover and investment spending. Finally, they could provide insights into the evolution of specific industries: e.g., the electric industry is undergoing deregulation and we are observing numerous mergers involving firms of different sizes. Also, uncertainty about prices and profits with sharp fluctuations during 1998 and 1999, and 2000 in specific regions in the U.S., are well documented resulting in many utilities experiencing financial distress. While a detailed study would be required to examine this industry's evolution, our findings could be used to predict a future path that leads to weeding out of smaller firms and greater concentration.

\section{Uncertainty and Sunk Costs}

\section{II(i). Option Value}

Dixit (1989), Dixit and Pindyck (1994) and Caballero and Pindyck (1996) provide a broad framework to 
structure our empirical analysis using industry data. ${ }^{4}$ To streamline our discussion, we introduce some notation. Let $\Omega(\mathbf{K})$ be the sunk entry capital investment - sunk costs are assumed proportional to the entry capital requirement; $\mathbf{Z}$ the stochastic element with the conditional standard deviation of $\mathbf{Z}, \boldsymbol{\sigma}(\mathbf{Z})$, measuring uncertainty; ${ }^{5}$ and $\mathbf{P}^{\mathrm{H}}$ and $\mathbf{P}^{\mathbf{L}}$ the entry and exit trigger prices - over $\left(0, \mathrm{P}^{\mathrm{H}}\right)$ the potential entrant holds on to its option to enter, and over $\left(\mathrm{P}^{\mathrm{L}}, \infty\right)$ an incumbent does not exit. Dixit (1989) shows that uncertainty and sunk costs imply an option value of waiting for information and this raises $\mathrm{P}^{\mathrm{H}}$ and lowers $\mathrm{P}^{\mathrm{L}}$; entrants delay decisions as they require a premium over the conventional Marshallian entry price, and exit is delayed as incumbents know they have to re-incur sunk costs upon re-entry. Given $\sigma(Z)$, increase in $\Omega(K)$ widens the zone of inaction-Figure 1(a); given $\Omega(\mathrm{K})$, increase in $\sigma(\mathrm{Z})$ widens the zone-Figure 1(b). Caballero and Pindyck (1996) model the intertemporal path of a competitive industry where negative demand shocks decrease price along existing supply curve, but positive shocks may induce entry/expansion by incumbents, shifting the supply curve to the right and dampening price increase. Since the upside is truncated by entry but the downside is unaffected, it reduces the expected payoff from investment and raises the entry trigger. If exit is likely, it would create a price floor making firms willing to accept a period of losses. Their data on SIC 4-digit manufacturing industries (similar to ours) shows that sunk costs and industry-wide uncertainty cause the entry (investment) trigger to exceed the cost of capital.

For our empirical analysis, we would like to know the relative impacts of $\Omega(\mathrm{K})$ and $\sigma(\mathrm{Z})$ on $\mathrm{P}^{\mathrm{H}}$ and $\mathrm{P}^{\mathrm{L}}$; e.g., is $\mathrm{P}^{\mathrm{H}}$ affected more than $\mathrm{P}^{\mathrm{L}}$ or vice versa? Numerical simulations in Dixit and Pindyck $($ Ch. 7,8$)$ show that increase in $\sigma(\mathrm{Z})$ given $\Omega(\mathrm{K})$ - or increase in $\Omega(\mathrm{K})$ given $\sigma(\mathrm{Z})$ - results $\mathrm{P}^{\mathrm{H}}$ increasing by more than the decrease in $\mathrm{P}^{\mathrm{L}}$; it follows that increase in both $\sigma(\mathrm{Z})$ and $\Omega(\mathrm{K})$ will increase $\mathrm{P}^{\mathrm{H}}$ more than the decrease in $\mathrm{P}^{\mathrm{L}}$. These results imply that uncertainty and sunk costs affect entry more than exit leading to negative net entry; i.e., the intertemporal path of the industry is likely to show a decrease in the number of firms.

Turning to imperfect competition, first consider a duopoly setting (Dixit and Pindyck, p.309-315). Entry price still exceeds the Marshallian trigger due to uncertainty and sunk costs, preserving the option value of waiting. But, there are strategic considerations. Under simultaneous decision making, when price is $\epsilon$ above the entry trigger, neither firm wants to wait for fear of being preempted by its rival and losing leadership. This could lead to faster, simultaneous, entry than in the leader-follower sequential entry setting.

\footnotetext{
${ }^{4}$ Hopenhayn (1992), Lambson (1991) and Pakes and Ericsson (1998), e.g., study firm dynamics assuming firmspecific uncertainty. The latter also evaluate models of firm dynamics under active v. passive learning. These models can be better subjected to empirical evaluation using micro-datasets, as in Pakes and Ericsson.

${ }^{5}$ In the simplest settings, the models consider uncertainty about prices assuming constant input costs and technology. But Caballero and Pindyck (1996) and Dixit and Pindyck (1994), for example, discuss uncertainty about cash-flows, profits, among other variables. We return to this in Section IV(iii).
} 
So fear of pre-emption may necessitate a faster response and counteract the option value of waiting. Second, Appelbaum and Lim (1985), Dixit (1980) and Spencer and Brander (1992) show that it is optimal for the incumbent/first-mover to strategically pre-commit. But under uncertainty, optimal pre-commitment is lower due to greater uncertainty about the success of the entry-deterring strategy. Oligopolistic settings, therefore, highlight the dependence of outcomes on model assumptions and difficulties of arriving at clear predictions.

\section{II(i)(a). Links to Empirical Analysis}

We start by noting two issues. First, within-industry firm size distribution is typically skewed (Ijiri and Simon, 1977; Sutton, 1997.a). Our data (Section IV(i)) reveals this to be the typical characteristic. Previous studies show that (i) entrants are typically small compared to incumbents and have high failure rates, (ii) typical exiting firm is small and young, and (iii) larger firms are older with higher survival rates. ${ }^{6} \mathrm{We}$ address the small v. large firm issue in our empirical analysis. Second, our SIC 4-digit manufacturing industry data, which cover a 30-year span, contains information on the total number of firms and establishments (by size class) in an industry. Several studies have noted a positive correlation between entry and exit rates, implying that net entry data masks underlying turnover. However, these studies also indicate cross-industry variation in patterns of net entry. ${ }^{7}$ In Section IV(i) we show that our data contains reasonable "within-industry" time-series variation in net entry, which is encouraging for our empirical analysis.

We summarize the implications for industry dynamics as follows:

(A) Net entry. We noted that an increase in $\sigma(Z)$ given $\Omega(K)$ - or an increase in $\Omega(K)$ given $\sigma(Z)$ - is likely to result in negative net entry. Would these influences affect small v. large firms differentially?

Large firms are older and have "cumulatively" greater investments in, e.g., advertising and R\&D; see Sutton (1991, 1997.b) and Caves (1998). Advertizing and distribution networks contain sunk investments which erode upon exit and would have to be re-established if the firm re-enters in future; similarly exit entails loss of human and physical capital related to product and process innovation. Under this scenario, larger firms are more likely to show greater inaction regarding exit. Since data shows that

\footnotetext{
${ }^{6}$ See Audretsch (1995), Dunne et al. (1988), Evans (1987) and Sutton (1997.a). In Audretsch (p.73-80), mean size of the entering firm is 7 employees, varying from 4 to 15 across 2-digit industries. Audretsch (p.159) finds $19 \%$ of exiting firms have been in the industry less than 2 years with mean size of 14 employees; for exiting firms of all ages, the mean size is 23. Dunne et al. (p.503) note that about $39 \%$ of firms exit from one Census to the next and entry cohort in each year accounts for about $16 \%$ of an industry's output." While the number of entrants is large, their size is tiny relative to incumbents. Data indicate similar pattern for exiters.

${ }^{7}$ Dunne et al. (1988), for SIC 4-digit industries over 1963-82 Censuses (similar to ours), find raw correlations between entry and exit rates of 0.18 to 0.33 ; while positive, they are relatively low implying considerable variation in net entry patterns across industries. Also, after sweeping out industry fixed-effects, the correlations turn negative $(-0.028$ to -0.249$)$ overturning inference from raw data. Geroski (1995) discusses results for other countries.
} 
entrants are rather small, entry of large firms is typically not an important consideration. Overall, we expect greater inaction in large firm net entry (little/no entry and lower exits) under increased uncertainty.

As noted earlier, entry cohorts typically consist of relatively small firms, and exit cohorts of young and small firms. Based on the results discussed earlier, greater $\sigma(Z)$ delays entry more than exit, resulting in negative net entry; i.e., we can expect a decrease in the number of smaller firms. Further, this effect will be exacerbated when sunk entry capital investments, $\Omega(\mathrm{K})$, are higher.

(B) Size distribution. If there is greater attrition among small firms, then firm size distribution will become less skewed, and this effect will be more pronounced in high sunk cost industries.

(C) Concentration. Given the above, industry concentration would be expected to increase marginally since the smaller firms typically account for a trivial share of industry output.

\section{II(ii). Financing Constraints}

There is a well established literature examining the interaction between financial market frictions and firms' capital outlays. We highlight some results relevant for our study. First, consider uncertainty. Greenwald and Stiglitz (1990) model firms as maximizing expected equity minus expected cost of bankruptcy and examine scenarios where firms may be equity or borrowing constrained. A key result of theirs is that greater uncertainty about profits exacerbates information asymmetries, tightens financing constraints and reduces capital outlays. Because uncertainty increases risk of bankruptcy, firms cannot issue equity to absorb the risk. Gale and Hellwig (1985), within the context of a somewhat different model, derive results that are similar in spirit. Second, high sunk costs imply that lenders will be more hesitant to provide financing because greater asset specificity lowers resale value implying that collateral has less value (Williamson, 1988). ${ }^{8}$ In Shleifer and Vishny (1992), asset specificity is a determinant of leverage and explains crossindustry and intertemporal patterns of financing; the ease of debt financing is inversely related to asset specificity. Greater uncertainty and sunk costs, therefore, are expected to exacerbate financing constraints.

Since uncertainty and sunk costs increase the likelihood of bankruptcy and heighten financing constraints, incumbent firms who are more dependent on borrowing and are adversely affected by tighter credit constraints will experience lower probability of survival and expedited 'exits'. Firms more likely to be adversely affected are those with little/no collateral, inadequate history and shaky past performance.

\footnotetext{
${ }^{8}$ On asset recovery by debt holders, Williamson writes: (p.571) "Of the several dimensions with respect to which transactions differ, the most important is the condition of asset specificity. This has a relation to the notion of sunk cost..." (p.580) "In the event of default, the debt-holders will exercise pre-emptive claims against the assets in question....The various debt holders will then realize differential recovery in the degree to which the assets in question are redeployable...the value of a pre-emptive claim declines as the degree of asset specificity deepens..."
} 
Several studies have examined the impact of financing constraints on firm survival. Cooley and Quadrini (2000) model industry dynamics with financial market frictions; firms can finance capital outlays by issuing new shares or borrowing from financial intermediaries, but both are costly. Smaller/younger firms borrow more and have higher probability of default; with increasing size/age, the default probability falls dramatically. Due to financial frictions, smaller/younger firms have higher probability of exit. Empirical results in Cabral and Mata (2001) suggest that financing constraints cause lower survival probability and higher exit rates among small/young firms. Brito and Mello (1995) extend the framework of Greenwald and Stiglitz to show that small/young firm survival is adversely affected by financing constraints. Thus, via the financing constraints channel, we expect exits to increase. Similarly, 'entry' is likely to be retarded for potential entrants who are more adversely affected by the tighter credit conditions. Overall, greater uncertainty and sunk costs are likely to accelerate exits and retard entry; i.e., negative net entry.

\section{II(ii)(a). Links to Empirical Analysis}

A growing literature suggests that financial market frictions are more likely to affect small/young firms; e.g., Cabral and Mata (2001), Cooley and Quadrini (2000), Chan and Chen (1991), Evans and Jovanovic (1989), Fazzari, et al. (1988), and Gertler and Gilchrist (1994). The latter note (p. 314):

“...while size per se may not be a direct determinant, it is strongly correlated with the primitive factors that do matter. The informational frictions that add to the costs of external finance apply mainly to younger firms, firms with a high degree of idiosyncratic risk, and firms that are not collateralized. These are, on average, smaller firms."

Using this we postulate that small firms are more likely to be affected by financing constraints under greater uncertainty. In addition, this effect will be greater in industries with high sunk costs as lenders will be unable to recover much value from the collateral. The predictions can be summarized as follows:

(A) Net entry. For smaller firms, greater uncertainty, by tightening borrowing constraints, is likely to increase exits and lower entry; i.e., the industry will experience loss of smaller firms. In addition, these effects will be magnified in high sunk cost industries.

(B) Size distribution. If greater uncertainty causes negative net entry of smaller firms, the industry firm size distribution will become less skewed with the effect being more pronounced in high sunk cost industries.

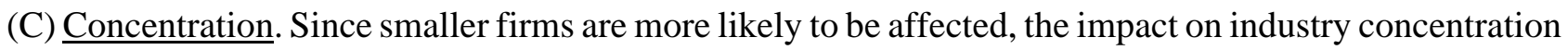
while positive, may not be quantitatively large.

\section{Technological Change and Other Factors}

\section{III(i). Technological Change}

We briefly outline insights from a class of models that link technological change to industry dynamics. Gort 
and Klepper (1982) visualize two types of innovations. Type I(2) results from major breakthroughs that may launch a new product cycle typically resulting in positive net entry into the industry. Type I(1) constitutes ongoing improvements emanating from incumbent firms which leads to lower costs and weeding out of inefficient firms resulting in negative net entry. Regarding I(1) innovations, Gort and Klepper (p.634) write:

"[this] innovation not only reinforces the barriers to entry but compresses profit margins of the less efficient producers who are unable to imitate the leaders from among the existing firms. Consequently,...the less efficient firms are forced out of the market."

Their data on 46 industries provides evidence on wide inter-industry variation in patterns of evolution and general confirmation of the link between technological change and net entry. Jovanovic and MacDonald (1994) and Klepper and Simons (2000) provide additional insights using data on the U.S. tire industry. These models assume a distribution of production efficiency across firms, improvements in efficiency levels due to learning-by-doing and imitation, and a low probability of successful innovations. Jovanovic and MacDonald consider the arrival of a drastic invention that decreases costs and the ensuing dynamics results in high negative net entry; a large number of first-generation firms exit, leaving behind bigger efficient survivors. In Klepper and Simons, each period gives rise to R\&D opportunities to lower costs; innovators enjoy greater profit margins than imitators due to their $R \& D$ activities. Due to increasing production efficiency, entry is reduced to a trickle and exits continue resulting in a reduction in the number of firms.

The above models assume convergence to steady state where industry structure becomes relatively static. But Sutton (1997.a, p.52) notes this is at odds with observed data which show high turnover of firms in mature industries. Audretsch (1995) finds significant turnover in mature industries and industry-wide innovation is (i) negatively associated with startups and survival of new firms and (ii) hastens small firm exit. Thus, even in mature industries, ongoing innovations are likely to play a key role in industry dynamics.

For our empirical analysis, we note that innovations occur continually and can be drastic or nondrastic; the latter likely to be more frequent. Incumbents and entrants are assumed to have a distribution of production efficiencies. An industry may experience negative net entry during non-drastic innovations as less efficient firms are weeded out. In contrast, drastic innovation may result in positive net entry in the short-run as it ushers in a new product cycle. Since industries have experienced myriad innovations over our sample period, we construct a measure of technical change (Section IV(iv)) and examine its impact on the number of small and large establishments and firms in an industry, and concentration.

\section{III(ii). Other Factors}

Several other factors influence industry dynamics. In our empirical work we explicitly consider two variables: industry growth -GROW- and profit margins - $\Pi$. Evidence on the link between GROW and entry 
appears mixed. Audretsch (1995, p.61-63) finds new startups are not affected by industry growth, but positively affected by macroeconomic growth. Data in Jovanovic and MacDonald (1994) indicate sharp decline in the number of firms when the industry was growing; also Klepper (1999). Some of the empirical papers in Geroski and Schwalbach (1991) and the discussion in Audretsch (Ch.3) indicate a tenuous link between GROW and industry structure. The link is probably conditioned on entry barriers, macroeconomic conditions and the phaze of the industry's life cycle. Regarding profit-margin $\Pi$, the expected sign is positive. But, as for GROW, it will be conditioned on other industry-specific and aggregate factors. In the absence of entry barriers, greater $\Pi$ signals lucrative markets and attract entry. However, some of the estimates presented in the papers in Geroski and Schwalbach indicate considerable variation in the coefficient of $\Pi$. Geroski (1995) notes that the reaction of entry to elevated profits appears to be slow.

For scale economies, advertizing and R\&D, we don't have explicit controls due to lack of timeseries data, but we note the following. First, scale economies are unlikely to have large short-run fluctuations; if so, an industry-specific constant, which we include in our dynamic panel data model, will capture aspects of this relatively time-invariant component. ${ }^{9}$ Second, our regression will contain a variable for technological change and one could argue this captures aspects of scale economies. Third, our model includes a lagged dependent variable; to the extent that this incorporates information on scale economies from the "recent past", it provides additional control. I am not aware of SIC 4-digit time-series data on advertising or R\&D for our industries over 1963-92. ${ }^{10}$ To the extent that part of R\&D and advertising intensities are in steady state levels and have a time-invariant component, this will be captured by the industry-specific constant. ${ }^{11}$ Since our empirical model includes a time-series in broad technological change, this may partly capture R\&D effects. Finally, since the lagged dependent industry structure variable captures information on advertising and R\&D from the recent past, it provides an additional control.

\footnotetext{
${ }^{9}$ In Section IV(ii), following Sutton (1991), we construct a measure of minimum efficient scale (MES) for 1972, '82 and '92 to proxy sunk entry costs. As noted there, the rank correlation between MES in 1972 and 1992 is 0.94. Data summary statistics for the end-points indicated little change in the MES proxy. This provides some justification for arguing that industry fixed-effect may capture an important part of MES.

${ }^{10}$ We examined alternate sources. FTC Line of Business data on advertising and R\&D are only available for 4 years; some data are 3-digit and some 4-digit. Advertising data from the U.S. Statistics of Income: Corporate Source Book are typically at the 3-digit level and some 2-digit and there are important gaps which prevents us from constructing a consistent time series. Thus, these data were not useful for our long time-series study.

${ }^{11}$ After controlling for industry fixed-effects, Domowitz et al. (1987) find that advertising has no effect on industry markup fluctuations. They find far greater cross-industry variation in advertising than within-industry and conclude (p.25) "that by 1958, most of the industries in our sample had reached steady-state rates of advertising" This indicates that industry-fixed-effects would capture an important part of the impact of advertising.
} 


\section{Measurement}

Our approach is as follows. First, (all variables are industry-specific): (i) we use time-series data to create measures of uncertainty; (ii) using insights in Kessides (1990) and Sutton (1991), construct measures of sunk costs and create low versus high sunk cost groups; and (iii) measure technical change and other control variables. Second, we examine the impact of uncertainty on the dynamics of industry structure (as captured by the number of firms and small and large establishments, and concentration) for our full sample as well as industries segmented into low v. high sunk cost groups. Our data disaggregation is at the SIC 4-digit level (see Appendix A). An important consideration in this choice was the availability of relatively long time-series which is critical for measuring uncertainty and technical change, as well as availability of data on industry structure and sunk costs for a large number of industries over time. The industry-specific annual time-series data are over 1958-94. Data on industry structure and sunk costs are from the 5-yearly Census of Manufactures; these data are not available annually, implying that in our empirical estimation we use data at a 5-yearly frequency. Below we describe the key variables.

\section{IV(i). Industry Structure}

Industry-specific time-series data from the 1963-92 Censuses include: (i) total number of firms - FIRMS; (ii) total number of establishments - ESTB; (iii) ESTB by size classes; and (iv) four-firm concentration ratio -CONC. An establishment is an economic entity operating at a location, and the number of employees measures size. Size classes available from the Census are (\#employees): 1-4; 5-9; 10-19;20-49; 50-99; 100249; 250-499; 500-999; 1,000-2,499; 22,500. First, the within-year cross-industry statistics in Table 1 show substantial variation in structural characteristics. For the typical industry, there are about 623 ESTB, 558 FIRMS and CONC of 39\%, and the data reveal a large share of small establishments. The distribution of the ratio ESTB/FIRMS shows that the $50^{\text {th }}, 75^{\text {th }}$ and $90^{\text {th }}$ percentile values are $1.1,1.3$ and 1.6 ; the mean being 1.09. The mean and median values imply near equivalence between the number of establishments and firms in an industry; this is roughly true even at the $90^{\text {th }}$ percentile. This overall picture conceals a well known fact: larger (typically, older) firms tend to be multi-establishment (and multi-product), whereas smaller (typically, newer) firms are likely to be single-establishment. For the "representative" industry, Figures 2(a)-2(g) display data on the establishment size distribution over our seven Census years. Typically, about $25 \%$ of the total number of establishments in an industry belong to the smallest size category, and only about $3 \%$ belong to the largest size group. Given the statistics of the ratio ESTB/FIRMS, figures 2(a)-2(g) also roughly displays the size distribution of firms. The data reveals a skewed size distribution for the typical industry as well as fluctuations in this distribution over time. The skewed size distribution has been well documented (Ijiri and Simon, 1977; Sutton 1997.a). 
Second, we examine the "within-industry" time-series data on industry structure variables: for our empirical analysis, it is important there be variation in this dimension. Table 2 presents the summary statistics. For the "representative" industry, the mean ESTB is 623 and within-industry standard deviation of 138, the coefficient of variation being 22\%; the statistics on ESTB by size classes and FIRMS indicate reasonable intertemporal within-industry variation. This is encouraging from the viewpoint of our empirical examination of the impact of uncertainty and sunk costs on industry dynamics. Of all the variables presented in Table 2, CONC has the lowest within-industry variation.

We will examine the impact of uncertainty and sunk costs on ESTB and by size class. ESTB data is used to construct relatively small v. large establishment groups. The U.S. Small Business Administration (State of Small Business: A Report of the President, 1990), e.g., classifies "small business" as employing "less than 500 workers"; this metric has been used in public policy deliberations and lending policies towards small businesses. Using this, \#employees $<500$ constitutes our basic small business group, and $\geq 500$ employees the large business group; Ghosal and Loungani (2000) provide discussion of this benchmark. However, 500 employees may arguably constitute a relatively large/wealthy business. Since there is no well defined scheme by which we can define "small", we create additional small business groups. Overall, our groups are: (i) All establishments; (ii) relatively large businesses with $\geq 500$ employees; (iii) small businesses with <500 employees; and (iv) even smaller businesses as classified by (a) <250 employees, (b) $<100$ employees and (c) <50 employees. We did not push the size categories to greater extremes at either end as this would magnify the uniqueness of the samples and render inference less meaningful.

\section{IV(ii). Uncertainty}

As noted in Section II, the stochastic element can be couched in terms of several relevant variables. We focus on a bottom line measure: profit-margins. Arguably, profit-margins are important for firms making entry and exit decisions. Commenting on the industry-specific determinants of turnover of firms, Sutton (1997.a, p.52-53) notes the primary importance of volatility of industry profits; Dixit and Pindyck, and Caballero and Pindyck discuss uncertainty about profits and cash-flows. We assume that firms use a profit forecasting equation to predict the level of future profits. The forecasting equation filters out systematic components. The standard deviation of residuals, which represent the unsystematic component, measure profit-margin uncertainty. ${ }^{12}$ We measure industry profits as short-run profits per unit of sales. Labor, energy and intermediate materials are assumed to be the relatively variable inputs that comprise total variable costs.

\footnotetext{
${ }^{12}$ This is similar to, e.g., Aizenman and Marion (1997), Ghosal and Loungani (1996, 2000), Huizinga (1993) and Leahy and Whited (1996) who use the (conditional) standard deviation to measure uncertainty.
} 
Short-run profits are defined as: $:^{13} \Pi=[($ Sales Revenue minus Total Variable Costs)/(Sales Revenue $)]$. The standard deviation of the unsystematic component of $\Pi$ measures uncertainty. ${ }^{14}$ In Section VI we construct an alternate measure of profit-margins which accounts for depreciation and measure uncertainty using this.

For our benchmark measure of uncertainty, the profit forecasting equation includes lagged values of industry-specific sales growth (SALES) and economy-wide unemployment rate (UN). The justification for such a specification is contained in studies by Domowitz, et al. (1986), Ghosal (2000) and Machin and VanReenen (1993) which show the sensitivity of margins to industry-specific and aggregate conditions. The profit forecasting equation is given by $(1)$, where $\Pi_{i, t}$ is the profit-margin of industry ' $i$ ' in time ' $t$ ':

$$
\Pi_{\mathrm{i}, \mathrm{t}}=\lambda_{0}+\lambda_{1} \Pi_{\mathrm{i}, \mathrm{t}-1}+\lambda_{2} \Pi_{\mathrm{i}, \mathrm{t}-2}+\lambda_{3} \mathrm{SALES}_{\mathrm{i}, \mathrm{t}-1}+\lambda_{4} \mathrm{SALES}_{\mathrm{i}, \mathrm{t}-2}+\lambda_{5} \mathrm{UN}_{\mathrm{t}-1}+\lambda_{6} \mathrm{UN}_{\mathrm{t}-2}+\epsilon_{\mathrm{i}, \mathrm{t}}
$$

We use the following procedure to create a time-series for profit uncertainty:

(i) For each industry in our sample, we first estimate equation (1) using annual data over the entire sample period 1958-1994. ${ }^{15}$ The residuals represent the unsystematic components.

(ii) We use the standard deviation of residuals $-\boldsymbol{\sigma}(\boldsymbol{\Pi})_{\mathbf{i}, \mathbf{t}}$ as our uncertainty measure, where " $\mathrm{i}$ " and " $\mathrm{t}$ " index industry and time. As noted earlier, industry structure data are for 1963, '67, '72, '77, '82, '87 and '92. The s.d. of residuals over, e.g., 1967-71 serves as the uncertainty measure for 1972; similarly, s.d. of residuals over 1982-86 measures uncertainty for 1987 , and so on. We get seven time-series observations on $\sigma(\Pi)_{i, t^{*}}{ }^{16}$

${ }^{13}$ This is consistent with the definition of short-run profits (Varian, 1992, Ch.2); see Domowitz et al. (1986), Geroski and Mueller (1990), Ghosal (2000) and Machin and Van Reenen (1993) for empirical use of this measure. Carlton and Perloff (1994, p.334-343) and Schmalensee (1989) discuss alternate measures and their pitfalls. Our measure $\Pi$ does not control for capital costs; Carlton and Perloff and Schmalensee note quantifying capital costs is difficult due to problems related to valuing capital and assessing depreciation.

${ }^{14}$ Our industry level analysis implies that our procedure for measuring $\Pi$ and uncertainty reflects industry-wide average, or "typical", outcomes. Given that there is a distribution of firm sizes, idiosyncratic uncertainty is likely to be important and the true amount of uncertainty facing a particular firm may deviate from that for a typical firm. These issues can be better addressed within the framework of firm or establishment level datasets.

${ }^{15}$ We present some summary statistics from the regressions -equation (1)- estimated to measure uncertainty. Across the 267 industries, the mean Adjusted- $\mathrm{R}^{2}$ and the standard deviation of adjusted- $\mathrm{R}^{2}$ were 0.62 and 0.25 , respectively. The first-order serial correlation was typically low, with the cross-industry mean (std. dev across industries) being -0.002 (0.07). Overall, the fit of the industry regressions was reasonable.

${ }^{16}$ We considered alternate procedures. First, we used Autoregressive Conditional Heteroscedasticity (ARCH) models to measure uncertainty. After imposing the restrictions (Hamilton, 1994, Ch. 21), we estimated secondorder ARCH for each of the 267 industries. For about $45 \%$ of the industries the estimation failed to converge; using alternate starting values, convergence criterion and order of the ARCH specification did not alleviate the problems. This is probably not surprising given the limited number of time-series observations per industry. Second, our estimation of equation (1) over the entire sample period implies assuming stability of the parameters 
Table 4 (column 1) presents within-year cross-industry summary statistics for $\sigma(\Pi)$. The s.d. is relatively high compared to the mean value indicating large cross-industry variation. Table 5 (row 1) presents the "within-industry" statistics. Key to our empirical analysis, the typical industry shows a ratio of withinindustry s.d. (0.0117) to mean (0.0236) of 50\%, indicating large within-industry variation in uncertainty.

To check robustness of our inferences, we experimented with alternate specifications for the profit equation to construct the uncertainty measure. These included: (i) varying the lag length of the explanatory variables in equation (1); (ii) following Ghosal (2000) and replacing the business cycle indicator, unemployment rate, by federal funds rate (FFR) and energy price growth (ENERGY); (iii) estimating an AR(2) model for the forecasting equation; and (iv) estimating the profit equation in growth rates instead of levels. We also experimented with an alternate measure of profit-margins that accounts for depreciation. Our basic inferences do not change. In Section VI we present additional details and results to confirm this.

\section{IV(iii). Sunk Costs}

The theoretical models (Section II) assume that sunk costs are proportional to entry capital requirements, and, as they increase, the option value of waiting under uncertainty rises. Measurement of sunk cost presents difficult problems and there is little systematic empirical work that allows us to obtain good measures for a wide range of industries. We adopt the methodology outlined in Kessides (1990) and Sutton (1991) to quantify sunk costs. Drawing on the contestable markets literature, Kessides (1990) notes that the extent of sunk capital outlays incurred by a potential entrant will be determined by the durability, specificity and mobility of capital. While these characteristics are unobservable, he constructs proxies. Let RENT denote the fraction of total capital that a firm (entrant) can rent: RENT=(rental payments on plant and equipment/capital stock). Let USED denote the fraction of total capital expenditures that were on used capital goods: USED=(expenditures on used plant and equipment/total expenditures on new and used plant and equipment). Finally, let DEPR denote the share of depreciation payments: $\mathbf{D E P R}=($ depreciation payments/capital stock). High RENT implies that a greater fraction of capital can be rented by firms (entrants), implying lower sunk costs. High USED signals active market for used capital goods which firms (entrants) have access to, implying lower sunk costs. ${ }^{17}$ High DEPR indicates that capital decays rapidly,

\footnotetext{
${ }^{16}$ (...continued)

in (1) over the entire period. If we had longer time-series, or higher frequency data (quarterly), we could carry out sub-sample estimation of (1). But due to the relatively short time series, we did not pursue this angle.

${ }^{17}$ RENT and USED can be thought of as useful proxies in the sense that due to the 'lemons' problem many types of capital goods suffer sharp drop in resale price in a short time period; e.g., automobile resale prices drop the most in the first year or two. If new entrants have access to rental or used capital, their entry capital
} 
implying lower sunk costs (which arise from the undepreciated portion of capital). We collected data to construct RENT, USED and DEPR for Census years 1972, 1982 and 1992. ${ }^{18}$

Next, we proxy sunk costs following Sutton (1991). Let $\Phi(>0)$ be the setup cost or the minimal level of sunk cost an entrant must incur, and S denote industry sales (market size). In theory, $\Phi / \mathrm{S}$ is the sunk cost relative to market size. In quantifying setup/sunk costs, Sutton (1991, Ch.4) measures the relative level of setup costs across industries and sunk costs are assumed proportional to the cost of constructing a single plant of minimum efficient scale (MES). Let $\Omega$ measure MES, where $\Omega$ is output of the median plant relative to industry output. Assume capital-sales ratio of the median firm is the same as the industry as a whole and denote industry capital-sales ratio by $\mathrm{K} / \mathrm{S}$. Then $(\Phi / \mathrm{S})=\Omega(\mathrm{K} / \mathrm{S})$. If we can proxy $\Omega$, and have data for industry $\mathrm{K}$ and $\mathrm{S}$, we can approximate $\Phi / \mathrm{S} . \Omega$ is constructed using distribution of plants within each SIC 4-digit industry according to employment size. Let ' $m$ ' be the number of group sizes within the industry, and $n_{j}$ and $S_{j}$ denote number of plants and total sales of the $j^{\text {th }}$ size group $(j=1, \ldots, m$.). Let $\mathrm{Ms}_{\mathrm{j}}=\left(\mathrm{S}_{\mathrm{j}} / \mathrm{n}_{\mathrm{j}}\right) ; \mathrm{S}_{\mathrm{e}}=(1 / \mathrm{m}) \sum_{\mathrm{j}}\left(\mathrm{Ms}_{\mathrm{j}}\right)$; and $\mathrm{S}_{\mathrm{o}}=\sum_{\mathrm{j}} \mathrm{S}_{\mathrm{j}}$. Then $\Omega=\left(\mathrm{S}_{\mathrm{e}} / \mathrm{S}_{\mathrm{o}}\right)$. Using $\Omega$ and industry K/S, we obtain a proxy for $\Phi / \mathrm{S}$. We label $\Omega(\mathrm{K} / \mathrm{S}$ ) as SUNK(EC) (sunk costs-entry capital). Sutton (p.98) uses the cross-industry variation in $\operatorname{SUNK}(\mathrm{EC})$ to proxy cross-industry variation in sunk costs, and notes several limitations. ${ }^{19}$ In addition, we note that SUNK(EC) is based on an estimate of the "median plant size" of incumbents. As noted in Section II(i)(a), the typical entrant is very small compared to incumbents, and it takes time for new entrants to attain optimal scale. This implies that the median plant size typically overstates the entry capital requirements. Further, this bias may be greater in industries where optimal scale is relatively large, since the entrant will be farther away from optimal scale; where the median plant size is small, new entrants are more likely to be closer to this size. We calculated SUNK(EC) for the Census years 1972, 1982 and 1992 (same time periods as for USED, RENT and DEPR).

Sunk Cost Sub-Samples: Table 3 presents summary statistics for RENT, USED, DEPR and SUNK(EC).

\footnotetext{
${ }^{17}($...continued $)$

expenditures will have a lower sunk component. The availability of, e.g., used or leased aircraft, a prevalent feature of that industry, makes life somewhat easier for start-up airlines.

${ }^{18}$ Collecting these for some of the additional (and earlier) years presented particular problems due to changing industry definitions and many missing data points.

${ }^{19}$ E.g., (i) he assumes the K/Q ratio of the median plant is representative of the entire industry, and this is unlikely; (ii) book values are used to compute K/Q, but book values underestimate current replacement cost; (iii) the computation assumes that the age structure of capital does not vary across industries, and this is unrealistic.
} 
The measures show cross-industry variation given the standard deviation relative to the mean. ${ }^{20}$ We took a closer look at our measures for the end-points, 1972 and 1992. For the minimum efficient scale, MES, proxy $\Omega$ the rank correlation is 0.94 and 0.92 for $\operatorname{SUNK}(\mathrm{EC})$, indicating fair amount of stability in the MES and SUNK(EC) measures. The mean (s.d.) for MES and SUNK(EC) were similar over the end-points; the mean (s.d.) for USED, RENT and DEPR were relatively similar across time. We employ two strategies to segment samples. First, we use the cross-industry median values of each of the sunk cost proxies to create high v. low sunk cost sub-samples. If $\operatorname{SUNK}(\mathrm{EC})<50^{\text {th }}$ percentile, indicating relatively lower entry capital requirements, then sunk costs are low; high if $\operatorname{SUNK}(\mathrm{EC}) \geq 50^{\text {th }}$ percentile. Similarly, sunk costs are low if RENT or USED or DEPR $\geq 50^{\text {th }}$ percentile; high if RENT or USED or DEPR $<50^{\text {th }}$ percentile. Second, we created sub-samples by combining alternate characteristics, the argument being that they may produce stronger separation between low and high sunk costs. For example, sunk costs would be low if the intensity of rental and used capital markets are high and depreciation is high. More specifically, low sunk costs if "USED and RENT and DEPR $\geq 50^{\text {th }}$ percentile"; high if "RENT and USED and DEPR $<50^{\text {th }}$ percentile". Finally, low sunk costs if "USED and RENT and DEPR $\geq 50^{\text {th }}$ and SUNK(EC) $<50^{\text {th }}$ percentile"; high if "RENT and USED and DEPR $<50^{\text {th }}$ percentile and SUNK(EC) $\geq 50^{\text {th }}$ percentile".

\section{IV(iv). Technology}

For our analysis we need a time-series in technological change. Gort and Klepper (1982), Jovanovic and MacDonald (1994), Klepper and Simons (2000) and Klepper (1999) use specific innovations for selected industries. But, these data are not available for our 267 industries over 1958-92. Cohen and Levin (1989) note the considerable difficulties in measuring innovation. One set of measures are R\&D and patents, but time-series data are not available for our industries. Further, Cohen and Levin, Audretsch (p.27-29) and papers in Griliches (1984) highlight problems linking R\&D expenditures to technological change and the ambiguities of patent data. Audretsch (1995) uses data on innovations commercially introduced in the U.S. in 1982, arguing this is a better indicator of 'actual' technological change than R\&D and patents. But we don't have long time-series for such data. Instead, we pursue an alternate strategy: we construct an industryspecific time-series for technological change and use this as our control variable.

We construct a factor-utilization-adjusted Solow technology residual following the insights in

\footnotetext{
${ }^{20}$ Kessides (1990, Table 1), using data for 1982, reports summary statistics on USED, RENT and DEPR: the mean (s.d) values are $0.094(0.100), 0.024$ (0.025) and 0.070 (0.018). Our corresponding values (reported in Table 3) averaged over 1972, 1982 and 1992 are roughly comparable.
} 
Burnside (1996) and Basu (1996). ${ }^{21}$ Burnside (1996) assumes that gross output $Q$ is a differentiable function of unobserved capital "services" $(\mathrm{S})$, labor hours $(\mathrm{H})$, materials $(\mathrm{M})$ and energy $(\mathrm{E}): \mathrm{Q}_{\mathrm{t}}=\mathrm{Z}_{\mathrm{t}} \mathrm{F}\left(\mathrm{S}_{\mathrm{t}}, \mathrm{H}_{\mathrm{t}}, \mathrm{M}_{\mathrm{t}}, \mathrm{E}_{t}\right)$, where $\mathrm{Z}$ represents exogenous technology shock. Assuming that $\mathrm{S}$ is proportional to materials usage (Basu, 1996), or energy consumption (Burnside, 1996), and competitive factor markets, the log-linear approximation to the production function gives us the adjusted technology residual TECH(1):

$$
\operatorname{TECH}(1)=\left[\Delta \mathrm{q}_{\mathrm{t}}-\left(\delta_{\mathrm{Kt}} \Delta \mathrm{m}_{\mathrm{t}}+\delta_{\mathrm{Ht}} \Delta \mathrm{h}_{\mathrm{t}}+\delta_{\mathrm{Mt}} \Delta \mathrm{m}_{\mathrm{t}}+\delta_{\mathrm{Et}} \Delta \mathrm{e}_{\mathrm{t}}\right)\right]
$$

where lower case letters denote logarithms, $\delta$ is input share in total revenue and $\Delta \mathrm{s}$ is replaced by $\Delta \mathrm{m}$ (Basu, 1996) or $\Delta \mathrm{e}$ (Burnside, 1996). Since, in our empirical analysis, our inferences were not affected whether we replaced $\Delta \mathrm{s}$ by $\Delta \mathrm{m}$ or $\Delta \mathrm{e}$, we use $\Delta \mathrm{m}$ as it is a broad measure of input usage. We use TECH(1) as our benchmark measure of technological change. ${ }^{22}$ Table 4 (col. 2) presents within-year cross-industry summary statistics on TECH(1). Table 5 (row 2) presents within-industry summary statistics. These data indicate high cross-industry as well as within-industry time-series variation in the rate of technological change.

\section{IV(v). Other Variables}

The final two variables are industry profit-margins - $\Pi$ - and growth - GROW. $\Pi$ is measured as described in Section IV(iii). The industry structure variable in period ' $t$ ' is explained by $\Pi$ over the preceding period; e.g., the number of firms in 1972 is explained by the mean level of $\Pi$ over 1967-1971. ${ }^{23}$ Apart from using

\footnotetext{
${ }^{21}$ Since cyclical utilization of inputs like capital imparts a procyclical bias to the basic Solow residual, Burnside et al. (1995) use electricity consumption to proxy utilization of capital and obtain corrected Solow residual; Burnside (1996) uses total energy consumption; and Basu (1996) materials inputs. The intuition is that materials and energy don't have cyclical utilization component and are good proxies for the utilization of capital; assuming constant capital stock, if capital utilization increases, then materials and energy usage will typically increase.

${ }^{22}$ In one specification, Burnside et al. (1996) assume Leontief technology and gross output Q is produced with materials $(\mathrm{M})$ and value-added $(\mathrm{V}): \mathrm{Q}_{\mathrm{t}}=\min \left(\alpha_{\mathrm{V}} \mathrm{V}_{\mathrm{t}}, \alpha_{\mathrm{M}} \mathrm{M}_{\mathrm{t}}\right)$, where $\alpha$ 's are constants. $\mathrm{V}$ is produced with CRS and using capital services $(\mathrm{S})$ and labor hours $(\mathrm{H})$ : $\mathrm{V}_{\mathrm{t}}=\mathrm{Z}_{\mathrm{t}} \mathrm{F}\left(\mathrm{H}_{\mathrm{t}}, \mathrm{S}_{\mathrm{t}}\right)$, where $\mathrm{Z}$ is the exogenous technology shock. Capital services $S$ is unobserved. In Burnside et al. (1996), $S$ is assumed proportional to electricity consumption; Burnside (1996) assumes it is proportional to total energy usage. Since we do not have data on electricity usage, we proxy $S$ by total energy usage $(E): E=\xi S$. Given this and the assumption of perfectly competitive factor markets, the factor utilization adjusted technology residual is: $\mathbf{T E C H}(2)=\left[\Delta \mathrm{v}_{\mathrm{t}}-\left(1-\alpha_{\mathrm{Kt}}\right) \Delta \mathrm{h}_{\mathrm{t}}-\alpha_{\mathrm{Kt}} \Delta \mathrm{e}_{\mathrm{t}}\right]$, where the lower-case letters denote logarithms of value-added, labor hours and energy (note that capital services is replaced by its proxy, energy usage). Using this approach to measure the technology residual did not alter our inferences.

${ }^{23}$ In theory, an entrant should rationally expect profit-margins to fall post-entry, implying that we construct expected post-entry margins. In section 2.1(a) we noted that the typical entrant is very small compared to incumbents; given their size it is unlikely that they'll have an impact on industry prices and margins. Further, our
} 
the mean level of $\Pi$, we also experimented with using the growth rate of $\Pi$ over the preceding period. Our key inferences did not change. Table 4 (column 3) and Table 5 (row 3) present the cross-industry and within-industry summary statistics on $\Pi$. Our proxy for industry growth is the mean rate of new (net) investment. New investment entails sunk costs; thus if new investment is increasing, it is likely to indicate expanding market opportunities. As is standard (e.g., Fazzari et al., 1988), we measure net investment by the ratio $\left(\mathrm{I}_{\mathrm{i}, \mathrm{l}} / \mathrm{K}_{\mathrm{i}, \mathrm{t}-1}\right)$, where $\mathrm{I}_{\mathrm{i}, \mathrm{t}}$ is total industry investment in the current period and $\mathrm{K}_{\mathrm{i}, \mathrm{t}-1}$ is the end of last period capital stock. The industry structure variable in period ' $t$ ' is explained by the mean rate of net investment over the preceding period; e.g., the number of firms in 1972 is explained by the mean rate of net investment over 1967-1971. Table 4 (column 3) and Table 5 (row 3) present the cross-industry and within-industry summary statistics on GROW. As a check of robustness, in Section VI we report estimates using industry sales growth as a proxy for growth; our results regarding uncertainty are not affected.

\section{Panel Data Model}

Entry and exit are not likely to occur instantaneously to restore an industry's equilibrium under changing conditions, and there is uncertainty regarding the time is takes to restore equilibrium. Given these considerations, we use a partial adjustment model to structure our empirical equation. Martin (1993, Ch.7), e.g., reviews studies that have used similar models. Denoting industry structure by STR, where STR could be ESTB (and by size groups), FIRMS or CONC, we get:

$$
\operatorname{STR}_{\mathrm{i}, \mathrm{t}}=\lambda \mathrm{STR}_{\mathrm{i}, \mathrm{t}}{ }^{*}-(1-\lambda) \mathrm{STR}_{\mathrm{i},-1}
$$

where $\mathrm{i}$ and $\mathrm{t}$ denote industry and time, STR* the equilibrium structure in period $\mathrm{t}$, and $\lambda$ the partialadjustment parameter. STR* is not observed and is modeled as a function of the following industry-specific variables: (i) profit uncertainty, $\sigma(\Pi)_{\mathrm{i}, \mathrm{t}}$; (ii) technological change, $\mathrm{TECH}(1)_{\mathrm{i}, \mathrm{t}}$; (iii) profit-margin, $\Pi_{\mathrm{i}, \mathrm{t}}$; and (iv) growth, GROW $\mathrm{i}_{\mathrm{i}, \mathrm{t}}$ Apart from (i)-(iv), the panel data model includes the following controls: (v) an industry-specific fixed-effect $\alpha_{\mathrm{i}}$ to control for unobserved factors that influence the long-run level of industry structure, STR. These include unobserved relatively time-invariant elements of scale economies, advertising and R\&D (see discussion in Section III(ii)); and (vi) an aggregate structure variable, ASTR,

\footnotetext{
${ }^{23}$ (...continued)

typical industry contains about 560 firms (see Tables 1 and 2); given this large base of incumbents, it appears unlikely that an increment of one (small) entrant would affect prices and margins. Thus, we do not attempt to construct measures of expected post-entry margins. Our approach implies that entrants assume pre-entry profitmargins will prevail post-entry, and this is meaningful given the entrants' size and the large number of incumbents.
} 
to control for manufacturing-wide effects common to all industries. Audretsch (1995, Ch.3), for example, finds that macroeconomic factors play an important role; ASTR will capture these aggregate effects.

Incorporating these features, the dynamic panel data model is given by:

$$
\mathrm{STR}_{\mathrm{i}, \mathrm{t}}=\alpha_{\mathrm{i}}+\xi_{1} \sigma(\Pi)_{\mathrm{i}, \mathrm{t}}+\xi_{2} \operatorname{TECH}(1)_{\mathrm{i}, \mathrm{t}}+\xi_{3} \Pi_{\mathrm{i}, \mathrm{t}}+\xi_{4} \mathrm{GROW}_{\mathrm{i}, \mathrm{t}}+\xi_{5} \mathrm{ASTR}_{\mathrm{t}}+\xi_{6} \mathrm{STR}_{\mathrm{i}, \mathrm{t}-1}+\epsilon_{\mathrm{i}, \mathrm{t}}
$$

In equation (4), STR, $\sigma(\Pi), \Pi$, GROW and ASTR are measured in logarithms; thus, these coefficients are interpreted as elasticities. TECH(1) is not measured in logarithms as it can be negative or positive (see Section IV(iv) for construction of TECH). Next, we clarify the setup of (4). Let STR $_{\mathrm{i}, \mathrm{t}}$ be FIRMS $\mathrm{i}_{\mathrm{i} 1972}$. Then $\sigma(\Pi)_{i, 1972}$ is standard deviation of residuals over 1967-1971; TECH(1) $)_{\mathrm{i}, 1972}$ the mean rate of technical change over 1967-71; $\Pi_{i, 1972}$ the mean profit-margin over 1967-71; GROW $_{i, 1972}$ the mean rate of net investment over

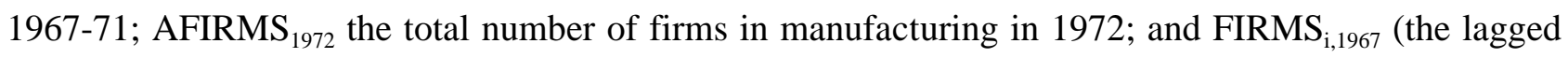
dependent variable) the total number of firms in the 4-digit industry in 1967. As discussed in Section III(ii), the lagged dependent industry structure variable will capture aspects of scale economies, and advertising and R\&D intensities using information from the recent past. We estimate (4) for all industries in our sample as well as the sunk cost sub-samples. Table 6 presents the summary statistics from our panel data.

\section{Estimation Method}

First, as shown in the literature on estimation of dynamic panel data models, we need to instrument the lagged dependent variable $\mathrm{STR}_{\mathrm{i}, \mathrm{t}-1}$. Second, industry-specific variables like number of establishments and firms, profit-margins, output, input usage, technical change (constructed from data on industry output and inputs) are all likely to be jointly-determined in industry equilibrium and are best treated as endogenous. Hausman tests (see notes to Table 7) easily reject the null that the industry variables are pre-determined. Several estimators have been proposed to obtain efficient and unbiased estimates in dynamic panel models; see, e.g., Baltagi (1994, Ch.8), Kiviet (1995). Our estimation proceeds in two steps. First, we sweep out the industry intercept $\alpha_{i}$ by taking deviations from within-industry means; the data are now purged of systematic differences across industries in the level of the relevant structure variable. Second, the withinindustry equation is estimated using the instrumental variable $(\mathbf{I V})$ estimator, treating $\sigma(\Pi)_{\mathrm{i}, \mathrm{t}}, \mathrm{TECH}(1)_{\mathrm{i}, \mathrm{t}}$, $\Pi_{i, t}$, GROW $_{i, t}$ and STR $_{\mathrm{i}, \mathrm{t}-1}$ as endogenous. We include a broad set of instruments as the literature indicates this is needed to alleviate problems related to bias and efficiency. The variables and their instruments are: (i) $\sigma(\Pi)_{\mathrm{i}, \mathrm{t}}$ is instrumented by $\sigma(\Pi)_{\mathrm{i}, \mathrm{t}-1}$ and $\sigma(\Pi)_{\mathrm{i}, \mathrm{t}-\mathrm{t}}$. In addition, since our data are over 5 -year time intervals (e.g., $\sigma(\Pi)_{\mathrm{i}, 1977}$ is constructed using data over 1972-1976), we also include instruments constructed at a higher level of aggregation that are likely to be correlated with $\sigma(\Pi)_{\mathrm{i}, \mathrm{t}}$ and uncorrelated with the error term. 
The objective is to provide a stronger overall set of instruments. We adopt the following procedure: we segment our data into durable (D) and non-durable (ND) goods industries. The business cycle literature indicates that these two types of industries show markedly different fluctuations. The 4-digit industries are roughly evenly split between D and ND. It is unlikely that any one D or ND 4-digit industry will influence all the D or ND industries; fluctuations in the entire D or ND group will be driven by factors exogenous to a given industry. Thus, instruments at the D/ND level appear reasonable. The instrument for $\sigma(\Pi)_{i, t}$ is the standard deviation of D/ND profit-margins over the relevant period. For example, for $\sigma(\Pi)_{i, 1977}$ the instrument is the standard deviation of $\Pi$ (for D and ND) over 1972-1976: we label this as $\boldsymbol{\sigma}(\boldsymbol{\Pi}$ : D/ND). (ii) For TECH(1) $)_{i, t}, \Pi_{i, t}$ and $\mathrm{GROW}_{\mathrm{i}, \mathrm{t}}$, we include their own two lags. As with uncertainty, we also include instruments constructed at the D/ND level: $\mathbf{T E C H}(1: \mathbf{D} / \mathbf{N D})_{\mathbf{t}}, \Pi(\mathbf{D} / \mathrm{ND})_{\mathbf{t}}$ and GROW(D/ND).

(iii) $\mathrm{STR}_{\mathrm{i}, \mathrm{t}-1}$ is instrumented by $\mathrm{STR}_{\mathrm{i}, \mathrm{t}-2}$ and manufacturing-wide $\mathrm{ASTR}_{\mathrm{t}}$ and $\mathrm{ASTR}_{\mathrm{t}-1}$ since ASTR can be treated as exogenous to a given 4-digit industry.

\section{Estimation Results}

\section{Estimates From the Full Sample}

Table 7 presents results from estimating equation (4). First, we focus on the $\sigma(\Pi)$ estimates; the coefficients are interpreted as elasticities since the industry structure variables and $\sigma(\Pi)$ are measured in logarithms. The coefficients are negative and significant for all establishments and the small establishment groups; the coefficient is positive and insignificant for the large establishment group. As establishment size decreases (e.g., Size<500; Size<250; Size<100; Size<50), the $\sigma(\Pi)$ elasticity gets larger. Thus, greater uncertainty primarily impacts smaller establishments. Greater $\sigma(\Pi)$ decreases FIRMS and increases CONC. Below we present the quantitative impact of a one-standard-deviation increase in $\sigma(\Pi)$.

\begin{tabular}{|c|c|c|c|c|c|c|c|}
\hline \multicolumn{6}{|c|}{ Number of Establishments by Size Group } & & \\
\hline Size: All & Size: $\geq 500$ & Size: $<500$ & Size: $<250$ & Size: $<100$ & Size: $<50$ & FIRMS & CONC \\
\hline-72 & +0.7 & -74 & -84 & -100 & -103 & -60 & +5 \\
\hline
\end{tabular}

A one-s.d. increase in $\sigma(\Pi)$ results in a drop of 60 FIRMS over the 5-year Census interval, starting from a mean value of 558 FIRMS (summary statistics in Table 6). For 'small' establishment groups, a one-s.d. increase in $\sigma(\Pi)$ leads to decrease of 75-100 establishments starting from sample mean values of 600-500. Finally, a one-s.d. increase in $\sigma(\Pi)$ results in 5 point increase in the four-firm concentration ratio, starting from a mean value of $39 \%$. The quantitative effects for the number of firms and establishments are clearly 
economically meaningful. While we have data on establishments by size groups, we only have data on the total number of firms. So we can't make a direct inference on whether the number of small or large firms are decreasing. But we can make an indirect inference. First, summary statistics presented in Section IV(i) indicate rough equivalence between an establishment and a firm with the $50^{\text {th }}\left(75^{\text {th }}\right)$ percentile value of the ratio [\#establishments/\#firms] being 1.1 (1.3). Second, the decline in the number of small establishments is roughly similar to the drop in number of firms. Thus, it appears reasonable to conclude there is a reduction in the number of small firms in an industry. Overall, uncertainty reduces the number of small firms and establishments, and increases industry concentration. Given the results on small v. large firms and establishments, we can say that the firm (establishment) size distribution becomes less skewed.

Next we turn to technical change, noting that $\operatorname{TECH}(1)$ is not measured in logarithms. Technological progress reduces the number of small establishments; the impact on large establishments is positive but insignificant. The point estimate of $\mathrm{TECH}(1)$ gets larger as establishment size gets smaller. Given the rough correspondence between small establishments and firms, greater TECH(1) reduces the number of small firms. The impact on industry CONC is positive, but the coefficient is not statistically significant. The table below shows the effect of a one-standard-deviation increase in TECH(1).

\begin{tabular}{|c|c|c|c|c|c|c|c|}
\hline \multicolumn{6}{|c|}{ Number of Establishments by Size Group } & \multirow[b]{2}{*}{ FIRMS } & \multirow[b]{2}{*}{ CONC } \\
\hline Size: All & Size: $\geq 500$ & Size: $<500$ & Size: $<250$ & Size: $<100$ & Size: $<50$ & & \\
\hline-26 & +0.1 & -26 & -32 & -38 & -40 & -22 & +1.6 \\
\hline
\end{tabular}

A one-s.d. increase in $\operatorname{TECH}(1)$ leads to a decrease of 40 firms over the 5-year Census interval, starting from a mean of 558 firms, and results in 1.6 point increase in CONC, starting from a mean of 39\%. Thus, technical change reduces the number of small firms and establishments, increases industry concentration and makes the firm (establishment) size distribution less skewed. Our estimates indicate that the quantitative effect of uncertainty on industry dynamics is greater than that of technological change.

Profit-margins, $\Pi$, appear to have no effect on the number of small establishments and firms, or in the full sample, but have a positive effect on the number of large establishments; industry CONC rises. Industry growth, GROW, has a negative and significant effect on the number of large establishments, and a weak negative effect in the full sample. The general ambiguity of the profit and growth results appear to be similar to those observed in some of the previous literature (see Section III(ii)). The industry structure variables in general co-vary positively with their aggregate (ASTR) counterparts; the exceptions being the number of large establishments. This indicates that the number of smaller firms and establishments are 
more sensitive to business cycle conditions. This finding is similar in spirit to those in Audretsch (Ch.3) where new firm startups were more sensitive to macroeconomic growth as compared to industry-specific growth. Finally, apart from CONC, the lagged dependent variables are positive and significant.

\section{Sunk Cost Sub-Samples}

Since the focus of our study is on the impact of uncertainty and sunk costs, in Table 8 we only present the $\sigma(\Pi)$ estimates. For ease of comparison, the first column reproduces the full-sample estimates from Table 7. The following observations emerge:

(i) For all establishments (Size All), greater $\sigma(\Pi)$ has a statistically significant negative effect only in the high sunk costs sub-samples. While the elasticities vary somewhat across the alternate sunk cost measures, the qualitative inferences are similar. The $\sigma(\Pi)$ elasticities are insignificant in the low sunk cost samples; (ii) For large establishments (Size $\geq 500$ ), $\sigma(\Pi)$ is statistically insignificant and positive. The exception being the DEPR high sunk cost sub-sample where the $\sigma(\Pi)$ coefficient is negative and significant;

(iii) Greater $\sigma(\Pi)$ reduces the number of small establishments only in the high sunk cost groups. And, as the size class get smaller (Size<500; ...; Size<50), the $\sigma(\Pi)$ elasticities get larger in the high sunk cost categories. The exception being the $\operatorname{SUNK}(\mathrm{EC})$ groups where greater $\sigma(\Pi)$ reduces the number of small establishments even when sunk cost are low, but the elasticities are larger in the high sunk cost group; and (iv) For FIRMS, the $\sigma(\Pi)$ elasticities are negative and significant only in the high sunk cost sub-samples. The only close call is for the low SUNK(EC) group where the elasticity is negative and close to significance at the $10 \%$ level. Given the rough equivalence between establishments and firms, and the results in (iii), uncertainty reduces the number of small firms in high sunk cost industries.

(v) The $\sigma(\Pi)$ elasticities are positive for the CONC regressions, but they are statistically significant only in the high sunk cost sub-samples.

Table 9 presents results from sunk cost sub-samples created by combining alternate measures (Section IV(ii)). The first column reproduces results from Table 7. While the results are similar to those in Table 8, the elasticities presented in Table 9 present a much starker effect of uncertainty on the dynamics of small establishments (firms). As before, uncertainty does not have an effect on the number of large establishments in an industry irrespective of the degree of sunk costs. Regarding industry dynamics, the broad picture emerging from Tables 8 and 9 is that greater uncertainty in conjunction with high sunk costs: (i) reduces the number of small establishments and firms; (ii) has no impact on the number of large establishments; (iii) results in a less skewed establishment (firm) size distribution (given (i) and (ii)); and (iv) leads to an increase in industry concentration. 


\section{Some Checks of Robustness}

To gauge the robustness of our uncertainty results, we carried out several checks. Some of these results are reported in Table 10. Since the focus of this paper is on the effect of uncertainty and sunk costs, we only report the $\sigma(\Pi)$ estimates. Panel A reproduces the estimates from Table 7 for easy reference.

(A) We experimented with alternate specifications for the profit forecasting equation (1). First, following Ghosal (2000), we replaced the broad business cycle indicator, unemployment rate, by the federal funds rate (FFR) and energy price growth (ENERGY) and constructed the uncertainty measure using these residuals; these results are in Panel B. Second, we estimated an AR(2) model; these results are in Panel C. (B) We constructed an alternate measure of industry profit-margins by accounting for depreciation expenses. The data on industry-specific depreciation rates were collected for the Census years 1972, 1982 and 1992 (same as those used to create the DEPR sub-samples). We assumed that the mean depreciation rate (over 72, 82 and 92) was representative for the full sample period and constructed the measure as: $\Pi(\mathbf{a l t})=[($ Total Sales Revenue-Total Variable Costs-Depreciation Expenses)/(Total Sales Revenue) . Using this measure, we reestimated equation (1) to construct $\sigma[\Pi$ (alt)]. We did not report these as our main results since we do not have a time-series in depreciation rates which would be required to make a proper comparison with our main measure $\sigma(\Pi)$. The results using $\sigma[\Pi($ alt $)]$ are in Panel D.

(C) In the main regression, we used the rate of new investment to proxy industry growth, GROW. We used an alternate measure, the growth of industry sales, and re-estimated equation (4); results are in Panel E. While in Table 10 we only report the equivalent of Table 7 estimates, we also examined the equivalent of Tables 8 and 9 sunk cost sub-sample estimates; we do not present the latter as they would be very space consuming. While there are some quantitative differences, experiments A-C did not alter our basic inferences from Tables 7-9.

We also experimented with the following: (i) varying the lag length of the explanatory variables in equation (1); (ii) estimating the profit forecasting equation in growth rates instead of levels; and (iii) an alternate instrument for $\sigma(\Pi)$ by constructing the (durable/non-durable) D/ND profit uncertainty instrument (Section V) by estimating a forecasting equation and using the residuals, instead of simply taking the standard deviation of D/ND profits. We used annual (1958-94) data on D and ND profit-margins and

separately estimated: $\Pi_{\mathrm{t}}=\tau_{0}+\tau_{1} \Pi_{\mathrm{t}-1}+\tau_{2} \Pi_{\mathrm{t}-2}+\tau_{3} \mathrm{SALES}_{\mathrm{t}-1}+\tau_{4} \mathrm{SALES}_{\mathrm{t}-2}+\tau_{5} \mathrm{UN}_{\mathrm{t}-1}+\tau_{6} \mathrm{UN}_{\mathrm{t}-2}+\epsilon_{\mathrm{t}}$. Uncertainty was constructed using standard deviation of residuals. These did not alter the inferences reported in Tables 7-9.

\section{Concluding Remarks}

Our results suggest that greater uncertainty about profits, in conjunction with higher sunk costs, have a quantitatively large negative impact on the survival rate of smaller firms, retard entry and lead to a less 
skewed firm size distribution; the impact on industry concentration is positive, but quantitatively small. Our findings shed light on some of the factors influencing industry dynamics and the evolution of firm size distribution, and lend support to Sutton's (1997.a, p.53) insight that fluctuations in industry profits may be of primary importance in understanding industry dynamics. How do these findings square up with respect to the option value and financing constraints channels discussed in Section II? For the option value channel, numerical simulations in Dixit and Pindyck indicated that the entry trigger was likely to increase by more than the decrease in the exit trigger implying negative net entry under greater uncertainty and sunk costs. And we argued that the preponderance of these effects would be felt by the relatively smaller firms. Our empirical findings appear supportive of this channel. Regarding financing constraints, uncertainty and sunk costs, which increase the probability of bankruptcy and exacerbate information asymmetries, were expected to affect smaller firms (incumbents and likely entrants) more than larger firms. Our empirical results also appear supportive of this channel. The broad nature of our data make it difficult to assess the relative importance of these two channels. Detailed longitudinal studies, along with data on entry and exit, may help disentangle the effects and provide deeper insights.

Technological change reduces the number of small firms and establishments, with little effect on larger establishments. Although we use a very different measure of technical change (variant of Solow residual) than employed in the previous literature ( $R \& D$, innovations, patents), our findings are similar in spirit to Audretsch (1995) who finds that greater rate of industry-wide innovation adversely affects new startups, favoring incumbents. Audretsch noted his findings were consistent with Winter's (1984) hypothesis of routinized technological regime. Our findings, however, also appear consistent with the notions outlined in, for example, Gort and Klepper (1982) and Klepper and Simons (2000) where incremental technical change decreases costs and forces out inefficient firms. Since the role of technology was not the central focus of our study, we did not attempt to differentiate across alternate channels via which technology affects industry dynamics. We investigate some these issues in Ghosal (2002). 


\section{References}

Agarwal, Rajshree and Michael Gort. "The Determinants of Firm Survival," Working Paper, SUNYBuffalo, (April) 1999.

Agarwal, Rajshree and Michael Gort. "The Evolution of Markets and Entry, Exit and Survival of Firms," Review of Economics and Statistics 78, 1996, 489-498.

Appelbaum, Elie, and Chin Lim. "Contestable Markets under Uncertainty," RAND Journal of Economics $16,1985,28-40$.

Audretsch, David. Innovation and Industry Evolution. Cambridge: MIT Press, 1995.

Baltagi, Badi. Econometric Analysis of Panel Data. New York: John Wiley, 1995.

Bartlesman, Eric, and Wayne Gray. "The Manufacturing Industry Productivity Database," National Bureau of Economic Research, 1998.

Basu, Susanto. "Procyclical Productivity: Increasing Returns or Cyclical Utilization?" Quarterly Journal of Economics 111, 1996, 719-751.

Baumol, William, John Panzar, and Robert Willig. Contestable Markets and the Theory of Industry Structure. San Diego: Harcourt Brace Jovanovich, 1982.

Brito, Paulo and Antonio Mello. "Financial Constraints and Firm Post-Entry Performance," International Journal of Industrial Organization 13, 1995, 543-565.

Burnside, Craig, Martin Eichenbaum and Sergio Rebelo. "Sectoral Solow Residuals," European Economic Review 40, 1996, 861-869.

Burnside, Craig, Martin Eichenbaum and Sergio Rebelo. "Capital Utilization and Returns to Scale," National Bureau of Economic Research Macroeconomics Annual, 1995, 67-119.

Caballero, Ricardo, and Mohamad Hammour. "The Cleansing Effect of Recessions," American Economic Review 84, 1994, 1350-1368.

Cabral, Luis and Jose Mata. "On the Evolution of the Firm Size Distribution: Facts and Theory," Working Paper, New York University, October 2001.

Caves, Richard. "Industrial organization and New Findings on the Turnover and Mobility of Firms," Journal of Economic Literature 36, 1998, 1947-1982.

Chan, K.C., and Nai-Fu Chen. "Structural and Return Characteristics of Small and Large Firms," Journal of Finance 46, 1991, 1467-1484.

Cohen, Wesley and Richard Levin. "Empirical Studies of Innovation and Market Structure" in Schmalensee, Richard and Robert Willig, ed., Handbook of Industrial Organization, Amsterdam: North Holland, (1989). 
Cooley, Thomas and Vincenzo Quadrini. "Financial Markets and Firm Dynamics," Working Paper, New York University, September 2000.

Davis, Steven, John Haltiwanger and Scott Schuh. Job Creation and Destruction. Cambridge: MIT Press, 1996.

Dixit, Avinash. "Entry and Exit Decisions under Uncertainty," Journal of Political Economy 97, 1989, 620638.

Dixit, Avinash, and Robert Pindyck. Investment under Uncertainty. Princeton: Princeton University Press, 1996.

Domowitz, Ian, Glenn Hubbard and Bruce Petersen. "Business Cycles and the Relationship Between Concentration and Price-Cost Margins," RAND Journal of Economics 17, 1986, 1-17.

Domowitz, Ian, Glenn Hubbard, and Bruce Petersen. "Oligopoly Supergames: Some Evidence on Prices and Margins," Journal of Industrial Economics 35, 1987, 379-98.

Dunne, Timothy, Mark Roberts, and Larry Samuelson. "Patterns of Entry and Exit in U.S. manufacturing industries," RAND Journal of Economics 19, 1988, 495-515.

Evans, David. "The Relationship Between Firm Growth, Size and Age: Estimates for 100 Manufacturing Industries," Journal of Industrial Economics 35, 1987, 567-581.

Evans, David and Boyan Jovanovic. "An Estimated Model of Entrepreneurial Choice under Liquidity Constraints," Journal of Political Economy 97, 1989, 808-827.

Fazzari, Steven, Glenn Hubbard and Bruce Petersen, "Financing Constraints and Corporate Investment." Brookings Papers on Economic Activity 1 (1988), 141-195.

Gale, Douglas, and Martin Hellwig. "Incentive-Compatible Debt Contracts: The One Period Problem," Review of Economic Studies 52, 1985, 647-663.

Geroski, Paul. “What do we know about Entry?” International Journal of Industrial Organization 13, 1995, 421-440.

Geroski, Paul, and Joachim Schwalbach. Entry and Market Contestability. Oxford: Blackwell, 1991.

Gertler, Mark, and Simon Gilchrist. "Monetary Policy, Business Cycles, and the Behavior of Small Manufacturing Firms," Quarterly Journal of Economics 108 (1994), 309-340.

Ghosal, Vivek, “Technological Change and the Evolution of Firm Size Distribution,” Mimeo, Georgia Institute of Technology, 2002.

Ghosal, Vivek. "Product Market Competition and Industry Price-Cost Margin Fluctuations: Role of Energy Price and Monetary Changes," International Journal of Industrial Organization 18, 2000, 415-444.

Ghosal, Vivek and Prakash Loungani. "The Differential Impact of Uncertainty on Investment in Small and Large Businesses," The Review of Economics and Statistics 82, 2000, 338-343. 
Ghosal, Vivek and Prakash Loungani. "Product Market Competition and the Impact of Price Uncertainty on Investment," Journal of Industrial Economics 44, 1996, 217-228.

Gort, Michael and Steven Klepper. "Time Paths in the Diffusion of Product Innovations," Economic Journal 92, 1982, 630-653.

Greenwald, Bruce and Joseph Stiglitz. "Macroeconomic Models with Equity and Credit Rationing," in Hubbard, R. Glenn. ed., Asymmetric Information, Corporate Finance, and Investment. Chicago: University of Chicago Press, 1990, 15-42.

Griliches, Zvi (ed). R\&D, Patents and Productivity. Chicago: University of Chicago Press, 1984.

Hopenhayn, Hugo. "Entry, Exit and Firm Dynamics in Long Run Equilibrium," Econometrica 60, 1992, $1127-1150$.

Ijiri,Yuji, and Herbert Simon. Skew Distributions and Sizes of Business Firms. Amsterdam: North Holland, 1977.

Jovanovic, Boyan and Peter Rousseau. "Mergers and Technological Change," Mimeo, University of Chicago, May 2001.

Jovanovic, Boyan and Glenn MacDonald. "The Life Cycle of a Competitive Industry," Journal of Political Economy 102, 1994, 322-347.

Kessides, Ioannis. "Market Concentration, Contestability and Sunk Costs," Review of Economics and Statistics 72, 1990, 614-622.

Kiviet, Jan. "On Bias, Inconsistency, and the Efficiency of Various Estimators in Dynamic Panel Data Models," Journal of Econometrics 68, 1995, 53-78.

Klepper, Steven and Kenneth Simons. "The Making of an Oligopoly: Firm Survival and Technological Change in the Evolution of the U.S. Tire Industry," Journal of Political Economy 108, 2000, 728-760.

Klepper, Steven. "Firm Survival and Oligopoly,” Mimeo, Carnegie Mellon University, 1999.

Lambson, Val. "Industry Evolution with Sunk Costs and Uncertain Market Conditions," International Journal of Industrial Organization 9, 1991, 171-196.

Machin, Stephen, and John Van Reenen, "Profit Margins and the Business Cycle: Evidence from U.K. Manufacturing Firms,” Journal of Industrial Economics 42 (1993), 29-50.

Martin, Stephen. Advanced Industrial Economics. Oxford: Blackwell, 1993.

Pakes, Ariel, and Richard Ericson. "Empirical Implications of Alternate Models of Firm Dynamics," Journal of Economic Theory 79, 1998, 1-45.

Schmalensee, Richard, "Inter-Industry Studies of Structure and Performance," in Schmalensee, Richard and Robert Willig, ed., Handbook of Industrial Organization, Amsterdam: North Holland, (1989). 
Shleifer, Andrei, and Robert Vishny. "Liquidation Values and Debt Capacity: A Market Equilibrium Approach,”Journal of Finance 47, 1992, 1343-1366.

Spencer, Barbara, and James Brander. "Pre-Commitment and Flexibility: Applications to Oligopoly Theory," European Economic Review 36, 1992, 1601-1626.

Stiglitz, Joseph, and Andrew Weiss. "Credit Rationing in Markets with Imperfect Information," American Economic Review, 1981, 393-410.

Sutton, John. Sunk Costs and Market Structure. Cambridge: MIT Press, 1991.

Sutton, John. “Gibrat's Legacy,” Journal of Economic Literature 35, 1997(a), 40-59.

Sutton, John. Technology and Market Structure. Cambridge: MIT Press, 1997(b).

Williamson, Oliver. "Corporate Finance and Corporate Governance,” Journal of Finance 43, 1988, 567591.

Winter, Sidney. "Schumpeterian Competition in Alternative Technological Regimes," Journal of Economic Behavior and Organization 5, 1984, 287-320. 


\section{Appendix A: Data}

The table below summarizes the data sources and years for which they are available. The industry data are at the SIC 4-digit level of disaggregation. The following industries were excluded from the sample:

(i) "Not elsewhere classified" since they do not correspond to well defined product markets;

(ii) Industries that could not be matched properly over time due to SIC definitional changes; there were important definition changes in 1972 and 1987. For these industries, the industry time-series and other structural characteristics data are not comparable over the sample period; and

(iii) Industries that had missing data on the industry structure and sunk cost variables.

The final sample contains 267 SIC 4-digit manufacturing industries. Given the above exclusions, the final sample contains industries that are relatively well defined over the sample period and have data consistency.

\begin{tabular}{|l|l|l|}
\hline Variable & Source & Years Available \\
\hline $\begin{array}{l}\text { Industry time-series data: } \\
\text { sales, investment, capital } \\
\text { stock, costs, etc. }\end{array}$ & $\begin{array}{l}\text { Bartlesman and Gray (1998). } \\
\text { Data are from Annual Survey } \\
\text { and Census of Manufacturing. }\end{array}$ & $1958-1994$ \\
\hline $\begin{array}{l}\text { Number of establishments and } \\
\text { by size groups }\end{array}$ & Census of Manufacturing & $1963,67,72,77,82,87,92$. \\
\hline Number of firms & Census of Manufacturing & $1963,67,72,77,82,87,92$. \\
\hline Four-firm concentration & Census of Manufacturing & $1963,67,72,77,82,87,92$. \\
\hline Used capital expenditures & Census of Manufacturing & $1972,82,92$. \\
\hline Rental payments & Census of Manufacturing & $1972,82,92$. \\
\hline Depreciation payments & Census of Manufacturing & $1972,82,92$. \\
\hline $\begin{array}{l}\text { Aggregate variables: } \\
\text { unemployment rate, federal } \\
\text { funds rate, energy prices. }\end{array}$ & $\begin{array}{l}\text { Economic Report of the } \\
\text { President. }\end{array}$ & $1958-1994$. \\
\hline
\end{tabular}




\begin{tabular}{|c|c|c|c|c|c|c|c|c|}
\hline \multirow[b]{3}{*}{ Year } & \multicolumn{6}{|c|}{ Number of Establishments by Size Class } & \multirow[b]{3}{*}{ FIRMS } & \multirow[b]{3}{*}{ CONC } \\
\hline & \multirow[b]{2}{*}{ Size: All } & \multirow{2}{*}{$\begin{array}{l}\text { Large } \\
\text { Size: } \geq 500\end{array}$} & \multicolumn{4}{|c|}{$\rightarrow$ Smaller $\rightarrow$} & & \\
\hline & & & Size: $<500$ & Size: $<250$ & Size: $<100$ & Size: $<50$ & & \\
\hline 1963 & $\begin{array}{r}639.9 \\
(1080)\end{array}$ & $\begin{array}{l}10.8 \\
(17)\end{array}$ & $\begin{array}{r}629.1 \\
(1079)\end{array}$ & $\begin{array}{r}614.3 \\
(1072)\end{array}$ & $\begin{array}{r}572.0 \\
(1037)\end{array}$ & $\begin{array}{l}518.1 \\
(972)\end{array}$ & $\begin{array}{r}587.9 \\
(1031)\end{array}$ & $\begin{array}{l}37.9 \\
(21)\end{array}$ \\
\hline 1967 & $\begin{array}{l}612.9 \\
(976)\end{array}$ & $\begin{array}{l}12.5 \\
(18)\end{array}$ & $\begin{array}{r}600.4 \\
(975)\end{array}$ & $\begin{array}{l}583.4 \\
(968)\end{array}$ & $\begin{array}{l}539.0 \\
(933)\end{array}$ & $\begin{array}{l}480.6 \\
(862)\end{array}$ & $\begin{array}{l}555.4 \\
(922)\end{array}$ & $\begin{array}{l}38.2 \\
(20)\end{array}$ \\
\hline 1972 & $\begin{array}{l}597.1 \\
(880)\end{array}$ & $\begin{array}{l}12.1 \\
(17)\end{array}$ & $\begin{array}{l}584.9 \\
(879)\end{array}$ & $\begin{array}{l}567.5 \\
(872)\end{array}$ & $\begin{array}{l}522.2 \\
(837)\end{array}$ & $\begin{array}{l}465.9 \\
(773)\end{array}$ & $\begin{array}{l}530.8 \\
(819)\end{array}$ & $\begin{array}{l}38.5 \\
(20)\end{array}$ \\
\hline 1977 & $\begin{array}{l}644.5 \\
(917)\end{array}$ & $\begin{array}{l}12.1 \\
(17)\end{array}$ & $\begin{array}{l}632.4 \\
(916)\end{array}$ & $\begin{array}{l}614.5 \\
(909)\end{array}$ & $\begin{array}{l}568.2 \\
(876)\end{array}$ & $\begin{array}{l}512.1 \\
(817)\end{array}$ & $\begin{array}{l}574.6 \\
(869)\end{array}$ & $\begin{array}{l}38.3 \\
(20)\end{array}$ \\
\hline 1982 & $\begin{array}{l}620.6 \\
(858)\end{array}$ & $\begin{array}{l}10.5 \\
(15)\end{array}$ & $\begin{array}{l}610.1 \\
(857)\end{array}$ & $\begin{array}{l}593.6 \\
(852)\end{array}$ & $\begin{array}{l}549.5 \\
(825)\end{array}$ & $\begin{array}{l}494.1 \\
(772)\end{array}$ & $\begin{array}{l}550.5 \\
(793)\end{array}$ & $\begin{array}{l}38.3 \\
(20)\end{array}$ \\
\hline 1987 & $\begin{array}{l}614.1 \\
(875)\end{array}$ & $\begin{array}{r}9.3 \\
(13)\end{array}$ & $\begin{array}{l}604.8 \\
(874)\end{array}$ & $\begin{array}{l}589.1 \\
(869)\end{array}$ & $\begin{array}{l}545.6 \\
(840)\end{array}$ & $\begin{array}{l}490.8 \\
(785)\end{array}$ & $\begin{array}{l}545.8 \\
(807)\end{array}$ & $\begin{array}{l}39.8 \\
(21)\end{array}$ \\
\hline 1992 & $\begin{array}{l}630.7 \\
(907)\end{array}$ & $\begin{array}{r}8.8 \\
(13)\end{array}$ & $\begin{array}{l}621.8 \\
(906)\end{array}$ & $\begin{array}{l}606.7 \\
(901)\end{array}$ & $\begin{array}{l}564.7 \\
(874)\end{array}$ & $\begin{array}{l}511.8 \\
(823)\end{array}$ & $\begin{array}{l}559.9 \\
(828)\end{array}$ & $\begin{array}{l}40.9 \\
(21)\end{array}$ \\
\hline Average & 623 & 11 & 612 & 596 & 552 & 496 & 558 & 39 \\
\hline
\end{tabular}

\section{Notes:}

1. The data cover 267 SIC 4-digit U.S. manufacturing industries over the seven Census years 1963-1992.

2. The numbers are the cross-industry mean value of the relevant industry structure variable; the corresponding standard deviations are in parentheses. For example, for 1992 the representative industry had about 560 firms and the s.d. of the number of firms was 828 . 


\begin{tabular}{|l|l|r|r|}
\hline \multirow{2}{*}{ Table 2. Within-Industry Across-Years: Industry Structure Summary Statistics } \\
\hline \multirow{3}{*}{ Size: All } & & Mean & \multicolumn{2}{|c|}{ Std. Deviation } \\
\hline \multirow{3}{*}{ Size: $\geq 500$} & Mean & 622.8 & 895.8 \\
\cline { 2 - 4 } & Std. Deviation & 138.3 & 233.9 \\
\hline \multirow{3}{*}{ Size: $<500$} & Mean & 10.8 & 15.2 \\
\cline { 2 - 4 } & Std. Deviation & 3.5 & 4.5 \\
\hline \multirow{2}{*}{ Size: $<250$} & Mean & 611.9 & 895.2 \\
\cline { 2 - 4 } & Std. Deviation & 137.7 & 233.3 \\
\hline \multirow{3}{*}{ Size: $<100$} & Mean & 595.6 & 889.2 \\
\cline { 2 - 4 } & Std. Deviation & 136.4 & 232.3 \\
\hline \multirow{3}{*}{ Size: $<50$} & Mean & 551.6 & 858.1 \\
\cline { 2 - 4 } & Std. Deviation & 130.3 & 228.2 \\
\hline \multirow{3}{*}{ FIRMS } & Mean & 496.2 & 799.1 \\
\cline { 2 - 4 } & Std. Deviation & 121.4 & 218.7 \\
\hline \multirow{3}{*}{ CONC } & Mean & 557.8 & 834.7 \\
\cline { 2 - 4 } & Std. Deviation & 129.2 & 234.3 \\
\hline & Mean & 38.8 & 20.0 \\
\cline { 2 - 4 } & Std. Deviation & 5.9 & 3.6 \\
\hline
\end{tabular}

Notes:

1. The data cover 267 SIC 4-digit U.S. manufacturing industries over the seven Census years 1963-92.

2. Row labeled "Mean": For each industry we computed the "within-industry" mean value of the relevant industry structure variable; we get 267 observations. This row presents the summary statistics for these means. For example, over the Census years 1963-92, the representative industry had about 558 firms.

3. Row labeled "Std. Deviation": For each industry we computed the "within-industry" standard deviation (s.d.) for the relevant industry structure variable. This column presents summary statistics for these s.d.'s. For example, for the number of firms the representative industry had a s.d. of about 129.

4. E.g., from 2 and 3, the typical industry had a "within-industry" mean number of firms of 558 and s.d. of 129. 


\section{Table 3. Sunk Cost Summary Statistics}

\begin{tabular}{|l|r|r|r|}
\hline & Median & Mean & Std. Dev. \\
\hline USED & 0.0795 & 0.0853 & 0.0454 \\
\hline RENT & 0.0180 & 0.0269 & 0.0284 \\
\hline DEPR & 0.0558 & 0.0577 & 0.0149 \\
\hline SUNK(EC) & 0.0055 & 0.0137 & 0.0602 \\
\hline
\end{tabular}

Notes:

1. USED is the share of used capital expenditures.

2. RENT is the share of rental capital expenditures.

3. DEPR is the share of depreciation expenditures.

4. SUNK(EC) is sunk entry capital requirements. 


\begin{tabular}{|l|r|r|r|r|}
\hline \multicolumn{6}{|c|}{ Table 4. Within-Year Across-Industries: Explanatory Variables Summary Statistics } \\
\hline Period & $\sigma(\Pi)$ & TECH $(1)$ & \multicolumn{1}{l|}{ GROW } \\
\hline $1958-62$ & 0.0175 & 0.0081 & 0.2425 & 0.0223 \\
& $(0.0140)$ & $(0.0226)$ & $(0.0881)$ & $(0.0122)$ \\
\hline $1963-66$ & 0.0203 & 0.0088 & 0.2576 & 0.0263 \\
& $(0.0120)$ & $(0.0190)$ & $(0.0876)$ & $(0.0097)$ \\
\hline $1967-71$ & 0.0213 & 0.0013 & 0.2681 & 0.0309 \\
& $(0.0127)$ & $(0.0212)$ & $(0.0851)$ & $(0.0118)$ \\
\hline $1972-76$ & 0.0289 & 0.0073 & 0.2731 & 0.0377 \\
& $(0.0184)$ & $(0.0265)$ & $(0.0809)$ & $(0.0136)$ \\
\hline $1977-81$ & 0.0239 & 0.0033 & 0.2757 & 0.0549 \\
& $(0.0143)$ & $(0.0257)$ & $(0.0838)$ & $(0.0214)$ \\
\hline $1982-86$ & 0.0275 & 0.0046 & 0.2832 & 0.0584 \\
& $(0.0155)$ & $(0.0243)$ & $(0.0922)$ & $(0.0228)$ \\
\hline $1987-91$ & 0.0262 & 0.0055 & 0.3086 & 0.0672 \\
& $(0.0190)$ & $(0.0241)$ & $(0.1005)$ & $(0.0270)$ \\
\hline
\end{tabular}

\section{Notes:}

1. The data cover 267 SIC 4-digit U.S. manufacturing industries over the period 1958-94.

2. The numbers are the cross-industry mean value of the relevant variable; the corresponding standard deviations are in parentheses. For example, for $\sigma(\Pi)$ the representative industry had value of 0.0175 and the s.d. of $\sigma(\Pi)$ was 0.014 . 


\begin{tabular}{|l|l|r|r|}
\hline \multicolumn{2}{|l|}{ Table 5. Within-Industry Across-Years: Explanatory Variables Summary Statistics } \\
\hline \multirow{2}{*}{$\sigma(\Pi)$} & & Mean & \multicolumn{2}{|c|}{ Std. Deviation } \\
\hline \multirow{2}{*}{ TECH(1) } & Mean & 0.0236 & 0.0094 \\
\cline { 2 - 4 } & Std. Deviation & 0.0117 & 0.0072 \\
\hline \multirow{2}{*}{ Mean } & Mean & 0.0070 & 0.0106 \\
\cline { 2 - 4 } & Std. Deviation & 0.0205 & 0.0099 \\
\hline \multirow{2}{*}{ GROW } & Mean & 0.2727 & 0.0825 \\
\cline { 2 - 4 } & Std. Deviation & 0.0358 & 0.0185 \\
\hline & Mean & 0.0425 & 0.0117 \\
\cline { 2 - 4 } & Std. Deviation & 0.0211 & 0.0091 \\
\hline
\end{tabular}

Notes:

1. The data cover 267 SIC 4-digit U.S. manufacturing industries over the period 1958-94.

2. Row labeled "Mean": For each industry we computed the "within-industry" mean value of the relevant variable; we get 267 observations. This row presents the summary statistics for these means. For example, over 1958-94, the representative industry had a $\sigma(\Pi)$ value of 0.0236 .

3. Row labeled "Std. Deviation": For each industry we computed the "within-industry" standard deviation (s.d.) for the relevant variable. This column presents summary statistics for these s.d.'s. For example, for $\sigma(\Pi)$ the representative industry had a s.d. of about 0.0117 .

4. E.g., using 2 and 3, the typical industry had a "within-industry" mean value of uncertainty of 0.0236 and s.d. of 0.0117 ; coefficient of variation being about $50 \%$. 


\begin{tabular}{|c|c|c|}
\hline & Mean & Standard Deviation \\
\hline Size: All & 622.8 & 929.1 \\
\hline Size: $\geq 500$ & 10.9 & 16.1 \\
\hline Size: $<500$ & 611.9 & 928.2 \\
\hline Size: $<250$ & 595.6 & 922.1 \\
\hline Size: $<100$ & 551.6 & 890.5 \\
\hline Size: $<50$ & 496.2 & 830.7 \\
\hline FIRMS & 557.8 & 869.3 \\
\hline CONC & 38.8 & 20.9 \\
\hline$\sigma(\Pi)$ & 0.0236 & 0.0158 \\
\hline $\mathrm{TECH}(1)$ & 0.0070 & 0.0236 \\
\hline$\Pi$ & 0.2727 & 0.0904 \\
\hline GROW & 0.0425 & 0.0242 \\
\hline
\end{tabular}

Notes: The dependent (industry structure) variables are the number of establishments and by size group - these are denoted by Size (.); number of firms, FIRMS; and industry four-firm output concentration, CONC. $\sigma(\Pi)$ is profitmargin uncertainty, TECH(1) is the rate of technological change, $\Pi$ is industry profit-margin and GROW is the expected growth of the industry as captured by the mean rate of new investment. 


\begin{tabular}{|c|c|c|c|c|c|c|c|c|}
\hline & & & Inc & Istry Structu & e Variable: & & & \\
\hline & & & Number of $\mathrm{E}$ & tablishments & & & & \\
\hline & Size: All & Size: $\geq 500$ & Size: $<500$ & Size: $<250$ & Size: $<100$ & Size: $<50$ & FIRMS & CONC \\
\hline$\sigma(\Pi)_{\mathrm{i}, \mathrm{t}}$ & $\begin{array}{r}-0.172 * * \\
(0.001)\end{array}$ & $\begin{array}{r}0.093 \\
(0.258)\end{array}$ & $\begin{array}{r}-0.178 * * \\
(0.001)\end{array}$ & $\begin{array}{r}-0.209 * * \\
(0.001)\end{array}$ & $\begin{array}{r}-0.268 * * \\
(0.001)\end{array}$ & $\begin{array}{r}-0.308 * * \\
(0.001)\end{array}$ & $\begin{array}{r}-0.159^{* *} \\
(0.003)\end{array}$ & $\begin{array}{r}0.191 * * \\
(0.005)\end{array}$ \\
\hline $\operatorname{TECH}(1)_{\mathrm{i}, \mathrm{t}}$ & $\begin{array}{r}-1.737 * \\
(0.057)\end{array}$ & $\begin{array}{r}0.492 \\
(0.729)\end{array}$ & $\begin{array}{r}-1.809^{*} \\
(0.074)\end{array}$ & $\begin{array}{r}-2.263 * * \\
(0.046)\end{array}$ & $\begin{array}{r}-2.943 * * \\
(0.028)\end{array}$ & $\begin{array}{r}-3.418^{* *} \\
(0.015)\end{array}$ & $\begin{array}{r}-1.642^{*} \\
(0.075)\end{array}$ & $\begin{array}{r}1.758 \\
(0.193)\end{array}$ \\
\hline$\Pi_{\mathrm{i}, \mathrm{t}}$ & $\begin{array}{r}0.089 \\
(0.504)\end{array}$ & $\begin{array}{l}0.421 * \\
(0.029)\end{array}$ & $\begin{array}{r}0.029 \\
(0.849)\end{array}$ & $\begin{array}{r}-0.025 \\
(0.879)\end{array}$ & $\begin{array}{r}0.001 \\
(0.995)\end{array}$ & $\begin{array}{r}0.042 \\
(0.837)\end{array}$ & $\begin{array}{r}0.046 \\
(0.725)\end{array}$ & $\begin{array}{r}0.507 * * \\
(0.028)\end{array}$ \\
\hline $\mathrm{GROW}_{\mathrm{i}, \mathrm{t}}$ & $\begin{array}{c}-0.041^{*} \\
(0.094)\end{array}$ & $\begin{array}{r}-0.304 * * \\
(0.001)\end{array}$ & $\begin{array}{r}-0.017 \\
(0.521)\end{array}$ & $\begin{array}{r}-0.003 \\
(0.916)\end{array}$ & $\begin{array}{r}0.012 \\
(0.726)\end{array}$ & $\begin{array}{r}0.004 \\
(0.924)\end{array}$ & $\begin{array}{r}-0.011 \\
(0.678)\end{array}$ & $\begin{array}{r}0.058 \\
(0.144)\end{array}$ \\
\hline $\mathrm{ASTR}_{\mathrm{t}}$ & $\begin{array}{r}0.002 * * \\
(0.001)\end{array}$ & $\begin{array}{r}0.001 \\
(0.778)\end{array}$ & $\begin{array}{r}0.002 * * \\
(0.001)\end{array}$ & $\begin{array}{r}0.002 * * \\
(0.001)\end{array}$ & $\begin{array}{r}0.003 * * \\
(0.002)\end{array}$ & $\begin{array}{r}0.004 * * \\
(0.001)\end{array}$ & $\begin{array}{r}0.001 * * \\
(0.037)\end{array}$ & $\begin{array}{r}0.074 * * \\
(0.003)\end{array}$ \\
\hline $\mathrm{STR}_{\mathrm{i}, \mathrm{t}-1}$ & $\begin{array}{r}0.252 * * \\
(0.001)\end{array}$ & $\begin{array}{r}0.261 * * \\
(0.001)\end{array}$ & $\begin{array}{r}0.261 * * \\
(0.001)\end{array}$ & $\begin{array}{r}0.253^{* *} \\
(0.007)\end{array}$ & $\begin{array}{r}0.233^{* *} \\
(0.005)\end{array}$ & $\begin{array}{r}0.208 * * \\
(0.016)\end{array}$ & $\begin{array}{r}0.267 * * \\
(0.001)\end{array}$ & $\begin{array}{r}-0.049 \\
(0.562)\end{array}$ \\
\hline $\begin{array}{l}\text { Panel Obs. } \\
\text { \#Industries }\end{array}$ & $\begin{array}{r}1335 \\
267\end{array}$ & $\begin{array}{r}1335 \\
267\end{array}$ & $\begin{array}{r}1335 \\
267\end{array}$ & $\begin{array}{r}1335 \\
267\end{array}$ & $\begin{array}{r}1335 \\
267\end{array}$ & $\begin{array}{r}1335 \\
267\end{array}$ & $\begin{array}{r}1335 \\
267\end{array}$ & $\begin{array}{r}1335 \\
267\end{array}$ \\
\hline
\end{tabular}

\section{Notes:}

1. As noted in Section V, the variables STR, $\sigma(\Pi)$, $\Pi$, GROW and ASTR in equation (7) are measured in logarithms; thus these coefficients can be interpreted as elasticities. TECH(1) is not measured in logarithms; thus the magnitude of these coefficients cannot be directly compared to others. For variable definitions, see notes to Table 6 and Section IV.

2. Specification (7) was estimated using the instrumental variables method; the instruments are described in Section V.

3. p-values (two-tailed test) computed from heteroscedasticity-consistent standard errors are in parentheses; ** and * indicate significance at least at the 5\% and $10 \%$ levels.

4. For all the columns, the Hausman test easily rejected the null (at least at the $1 \%$ level) that the industry-specific variables were pre-determined.

5. Variable definitions (see section IV): SIZE(.)-number of establishments in a given size group; FIRMS-number of firms; CONC-four firm concentration ratio; $\sigma(\Pi)$-profit margin uncertainty; TECH-technical change; П-profit margin; GROW-growth; ASTR-relevant aggregate structure variable. 


\begin{tabular}{|c|c|c|c|c|c|c|c|c|c|}
\hline & \multirow{3}{*}{$\begin{array}{l}\text { ALL } \\
\text { Industries }\end{array}$} & \multicolumn{8}{|c|}{ Sunk Cost Sub-Samples } \\
\hline & & \multicolumn{2}{|c|}{ USED } & \multicolumn{2}{|c|}{ RENT } & \multicolumn{2}{|c|}{ DEPR } & \multicolumn{2}{|c|}{ SUNK(EC) } \\
\hline & & Low Sunk & High Sunk & Low Sunk & High Sunk & Low Sunk & High Sunk & Low Sunk & High Sunk \\
\hline Size: $\geq 500$ & $\begin{array}{r}0.093 \\
(0.258)\end{array}$ & $\begin{array}{r}0.052 \\
(0.647)\end{array}$ & $\begin{array}{r}0.041 \\
(0.709)\end{array}$ & $\begin{array}{r}0.077 \\
(0.526)\end{array}$ & $\begin{array}{r}0.100 \\
(0.383)\end{array}$ & $\begin{array}{r}0.197 \\
(0.183)\end{array}$ & $\begin{array}{c}-0.188^{*} \\
(0.061)\end{array}$ & $\begin{array}{r}0.173 \\
(0.130)\end{array}$ & $\begin{array}{l}-0.035 \\
(0.771)\end{array}$ \\
\hline Size: $<500$ & $\begin{array}{r}-0.178^{* *} \\
(0.002)\end{array}$ & $\begin{array}{r}-0.052 \\
(0.498)\end{array}$ & $\begin{array}{c}-0.156^{*} \\
(0.092)\end{array}$ & $\begin{array}{r}0.055 \\
(0.451)\end{array}$ & $\begin{array}{r}-0.331 * * \\
(0.001)\end{array}$ & $\begin{array}{r}0.005 \\
(0.942)\end{array}$ & $\begin{array}{r}-0.287 * * \\
(0.001)\end{array}$ & $\begin{array}{r}-0.099 \\
(0.124)\end{array}$ & $\begin{array}{r}-0.175^{* *} \\
(0.035)\end{array}$ \\
\hline Size: $<50$ & $\begin{array}{r}-0.308 * * \\
(0.001)\end{array}$ & $\begin{array}{r}-0.112 \\
(0.213)\end{array}$ & $\begin{array}{r}-0.312 * * \\
(0.029)\end{array}$ & $\begin{array}{r}0.007 \\
(0.927)\end{array}$ & $\begin{array}{r}-0.553^{* *} \\
(0.001)\end{array}$ & $\begin{array}{r}-0.041 \\
(0.664)\end{array}$ & $\begin{array}{r}-0.464 * * \\
(0.001)\end{array}$ & $\begin{array}{c}-0.147 * \\
(0.060)\end{array}$ & $\begin{array}{r}-0.353^{* *} \\
(0.008)\end{array}$ \\
\hline FIRMS & $\begin{array}{r}-0.159 * * \\
(0.003) \\
\end{array}$ & $\begin{array}{r}-0.053 \\
(0.476) \\
\end{array}$ & $\begin{array}{r}-0.163 * \\
(0.065) \\
\end{array}$ & $\begin{array}{r}0.033 \\
(0.635) \\
\end{array}$ & $\begin{array}{r}-0.298 * * \\
(0.001) \\
\end{array}$ & $\begin{array}{r}0.007 \\
(0.926) \\
\end{array}$ & $\begin{array}{r}-0.281 * * \\
(0.001) \\
\end{array}$ & $\begin{array}{r}-0.099 \\
(0.125) \\
\end{array}$ & $\begin{array}{r}-0.144 * \\
(0.074) \\
\end{array}$ \\
\hline CONC & $\begin{array}{r}0.191 * * \\
(0.005)\end{array}$ & $\begin{array}{r}0.027 \\
(0.778)\end{array}$ & $\begin{array}{r}0.215^{* *} \\
(0.038)\end{array}$ & $\begin{array}{r}0.097 \\
(0.257) \\
\end{array}$ & $\begin{array}{r}0.278^{* *} \\
(0.009)\end{array}$ & $\begin{array}{r}0.142 \\
(0.206)\end{array}$ & $\begin{array}{r}0.203 * * \\
(0.017)\end{array}$ & $\begin{array}{r}0.009 \\
(0.903)\end{array}$ & $\begin{array}{r}0.214^{* *} \\
(0.047)\end{array}$ \\
\hline $\begin{array}{l}\text { Panel Obs. } \\
\text { \#Industries }\end{array}$ & $\begin{array}{r}1869 \\
267\end{array}$ & $\begin{array}{l}938 \\
134\end{array}$ & $\begin{array}{l}931 \\
133\end{array}$ & $\begin{array}{l}938 \\
134\end{array}$ & $\begin{array}{l}931 \\
133\end{array}$ & $\begin{array}{l}938 \\
134\end{array}$ & $\begin{array}{l}931 \\
133\end{array}$ & $\begin{array}{l}931 \\
133\end{array}$ & $\begin{array}{l}938 \\
134\end{array}$ \\
\hline
\end{tabular}

Notes: Only the uncertainty coefficients are presented (see Table 7 for additional details). We estimated equation (7) for each sunk cost sub-sample (see section IV(iii) and Table 3 for details). USED, RENT or DEPR greater than $50^{\text {th }}$ percentile constitutes the low sunk cost samples; high if these are less than $50^{\text {th }}$ percentile. SUNK(EC) less than $50^{\text {th }}$ percentile forms the low sunk costs sample; high if it is greater than $50^{\text {th }}$ percentile. $p$-values (two-tailed test) computed from heteroscedasticity-consistent standard errors are in parentheses; $* *$ and $*$ indicate significance at least at the $5 \%$ and $10 \%$ levels. 


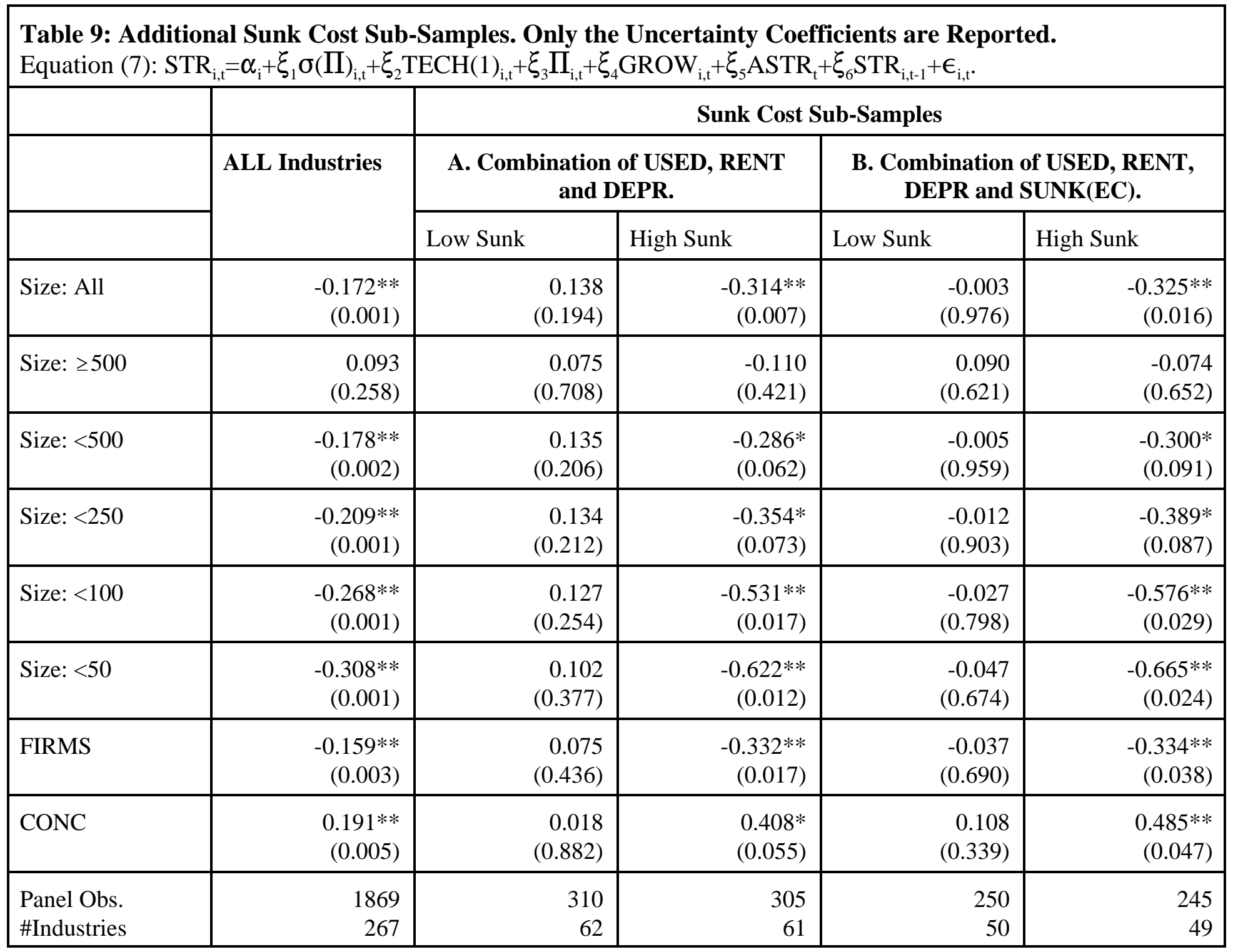

Notes: We estimated (7) for each sub-sample (see Tables 7 and 8 for details). Only the uncertainty coefficients are presented. In panel A, the combination "USED and RENT and DEPR greater than $50^{\text {th }}$ percentile" constitutes the low sunk cost sample; high if these are less than $50^{\text {th }}$ percentile. In panel B, the combination "USED and RENT and DEPR greater than $50^{\text {th }}$ percentile and SUNK(EC) less than $50^{\text {th }}$ percentile" forms the low sunk cost sample; high otherwise. 


\begin{tabular}{|c|c|c|c|c|c|c|c|}
\hline \multicolumn{6}{|c|}{ Number of Establishments } & \multirow[b]{2}{*}{ FIRMS } & \multirow[b]{2}{*}{ CONC } \\
\hline Size: All & Size: $\geq 500$ & Size: $<500$ & Size: $<250$ & Size: $<100$ & Size: $<50$ & & \\
\hline \multicolumn{8}{|c|}{ Panel A: Estimates from Table 7.} \\
\hline $\begin{array}{r}-0.172 * * \\
(0.001)\end{array}$ & $\begin{array}{r}0.093 \\
(0.258)\end{array}$ & $\begin{array}{r}-0.178^{* *} \\
(0.001)\end{array}$ & $\begin{array}{r}-0.209^{* *} \\
(0.001)\end{array}$ & $\begin{array}{r}-0.268 * * \\
(0.001)\end{array}$ & $\begin{array}{r}-0.308^{* *} \\
(0.001)\end{array}$ & $\begin{array}{r}-0.159^{* *} \\
(0.003)\end{array}$ & $\begin{array}{r}0.191 * * \\
(0.005)\end{array}$ \\
\hline \multicolumn{8}{|c|}{$\begin{array}{l}\text { Panel B: Uncertainty constructed from profit forecasting equation: } \\
\Pi_{\mathrm{i}, \mathrm{t}}=\lambda_{0}+\lambda_{1} \Pi_{\mathrm{i}, \mathrm{t}-1}+\lambda_{2} \Pi_{\mathrm{i}, \mathrm{t}-2}+\lambda_{3} \mathrm{SALES}_{\mathrm{i}, \mathrm{t}-1}+\lambda_{4} \mathrm{SALES}_{\mathrm{i}, \mathrm{t}-2}+\lambda_{5} \mathrm{FFR}_{\mathrm{t}-1}+\lambda_{6} \mathrm{FFR}_{\mathrm{t}-2}+\lambda_{7} \mathrm{ENERGY}_{\mathrm{t}-1}+\lambda_{8} \mathrm{ENERGY}_{\mathrm{t}-2}+\epsilon_{\mathrm{i}, \mathrm{t}}\end{array}$} \\
\hline $\begin{array}{r}-0.169 * * \\
(0.002)\end{array}$ & $\begin{array}{r}0.078 \\
(0.346)\end{array}$ & $\begin{array}{r}-0.178 * * \\
(0.002)\end{array}$ & $\begin{array}{r}-0.206 * * \\
(0.001)\end{array}$ & $\begin{array}{r}-0.258 * * \\
(0.001)\end{array}$ & $\begin{array}{r}-0.297 * * \\
(0.001)\end{array}$ & $\begin{array}{r}-0.152 * * \\
(0.006)\end{array}$ & $\begin{array}{r}0.179 * * \\
(0.010)\end{array}$ \\
\hline \multicolumn{8}{|c|}{$\begin{array}{l}\text { Panel C: Uncertainty constructed from an } \mathrm{AR}(2) \text { profit forecasting equation: } \\
\Pi_{\mathrm{i}, \mathrm{t}}=\lambda_{0}+\lambda_{1} \Pi_{\mathrm{i}, \mathrm{t}-1}+\lambda_{2} \Pi_{\mathrm{i}, \mathrm{t}-2}+\epsilon_{\mathrm{i}, \mathrm{t}}\end{array}$} \\
\hline $\begin{array}{r}-0.175 * * \\
(0.002)\end{array}$ & $\begin{array}{r}0.106 \\
(0.188)\end{array}$ & $\begin{array}{r}-0.176^{* *} \\
(0.003)\end{array}$ & $\begin{array}{r}-0.208 * * \\
(0.002)\end{array}$ & $\begin{array}{r}-0.267 * * \\
(0.001)\end{array}$ & $\begin{array}{r}-0.316^{* *} \\
(0.001)\end{array}$ & $\begin{array}{r}-0.164 * * \\
(0.004)\end{array}$ & $\begin{array}{r}0.146^{* * *} \\
(0.043)\end{array}$ \\
\hline \multicolumn{8}{|c|}{$\begin{array}{l}\text { Panel D: Same as in panel A, but the profit-margin measure accounts for depreciation expenses: } \\
\Pi(\text { alt })=[(\text { Total Sales Revenue-Total Variable Costs-Depreciation Expenses }) /(\text { Total Sales Revenue })] \text {. }\end{array}$} \\
\hline $\begin{array}{r}-0.170 * * \\
(0.001)\end{array}$ & $\begin{array}{r}0.071 \\
(0.341)\end{array}$ & $\begin{array}{r}-0.176^{* * *} \\
(0.001)\end{array}$ & $\begin{array}{r}-0.203 * * \\
(0.001)\end{array}$ & $\begin{array}{r}-0.263 * * \\
(0.001)\end{array}$ & $\begin{array}{r}-0.294 * * \\
(0.001)\end{array}$ & $\begin{array}{r}-0.138 * * \\
(0.004)\end{array}$ & $\begin{array}{r}0.158 * * \\
(0.010)\end{array}$ \\
\hline \multicolumn{8}{|c|}{ Panel E: Same as in Panel A, but GROW in equation (7) is growth of sales instead of the rate of new investment. } \\
\hline $\begin{array}{r}-0.189 * * \\
(0.001)\end{array}$ & $\begin{array}{r}0.058 \\
(0.484)\end{array}$ & $\begin{array}{r}-0.182 * * \\
(0.002)\end{array}$ & $\begin{array}{r}-0.200 * * \\
(0.001)\end{array}$ & $\begin{array}{r}-0.254 * * \\
(0.001)\end{array}$ & $\begin{array}{r}-0.291 * * \\
(0.001)\end{array}$ & $\begin{array}{r}-0.232 * * \\
(0.001)\end{array}$ & $\begin{array}{r}0.236^{* *} \\
(0.001)\end{array}$ \\
\hline
\end{tabular}

Notes: In Panel B, FFR denotes the federal funds rate and ENERGY the energy price growth. 


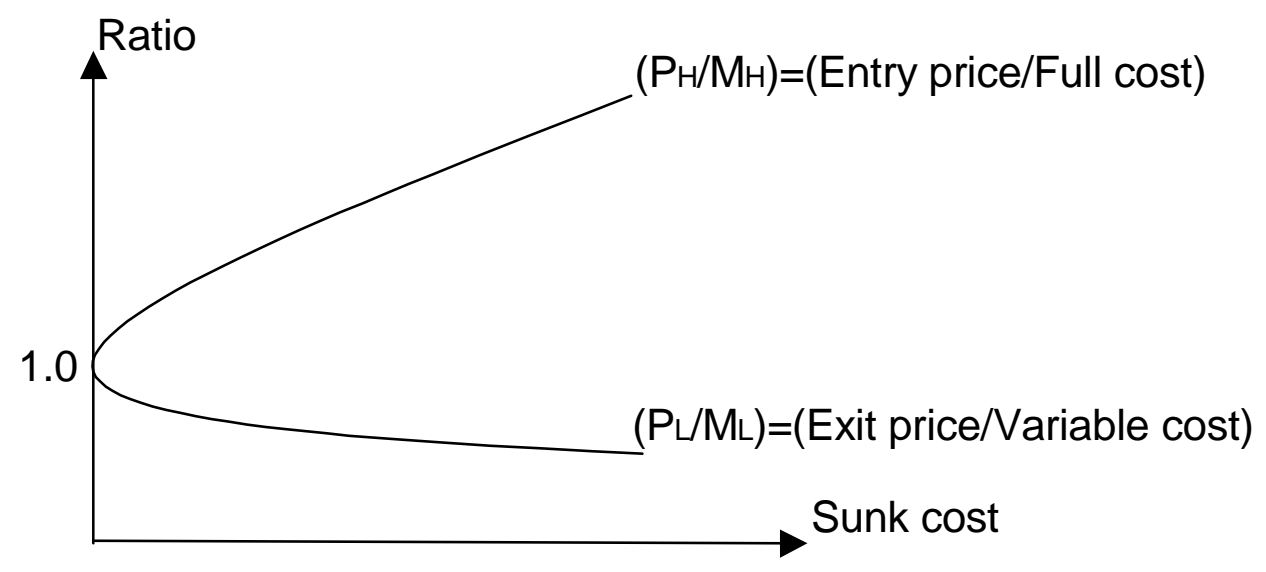

Figure 1(a). Increase in sunk cost and the entry/exit trigger

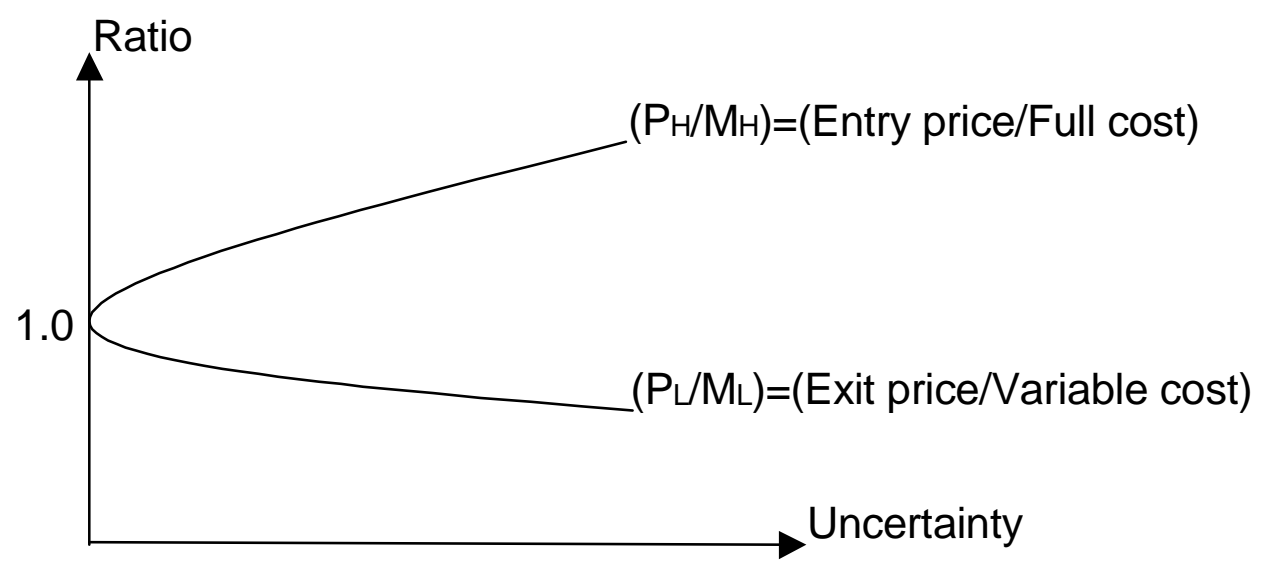

Figure 1(b). Increase in uncertainty and the entry/exit trigger

Note: $\mathrm{P}^{\mathrm{H}}$ and $\mathrm{P}^{\mathrm{L}}$ are the entry and exit trigger prices, and $\mathrm{M}^{\mathrm{H}}$ and $\mathrm{M}^{\mathrm{L}}$ are the conventional Marshallian entry and exit prices. For example, under zero uncertainty, $\mathrm{P}^{\mathrm{H}}=\mathrm{M}^{\mathrm{H}}\left(\mathrm{P}^{\mathrm{H}} / \mathrm{M}^{\mathrm{H}}=1\right)$ and $\mathrm{P}^{\mathrm{L}}=\mathrm{M}^{\mathrm{L}}\left(\mathrm{P}^{\mathrm{L}} / \mathrm{M}^{\mathrm{L}}=1\right)$. 

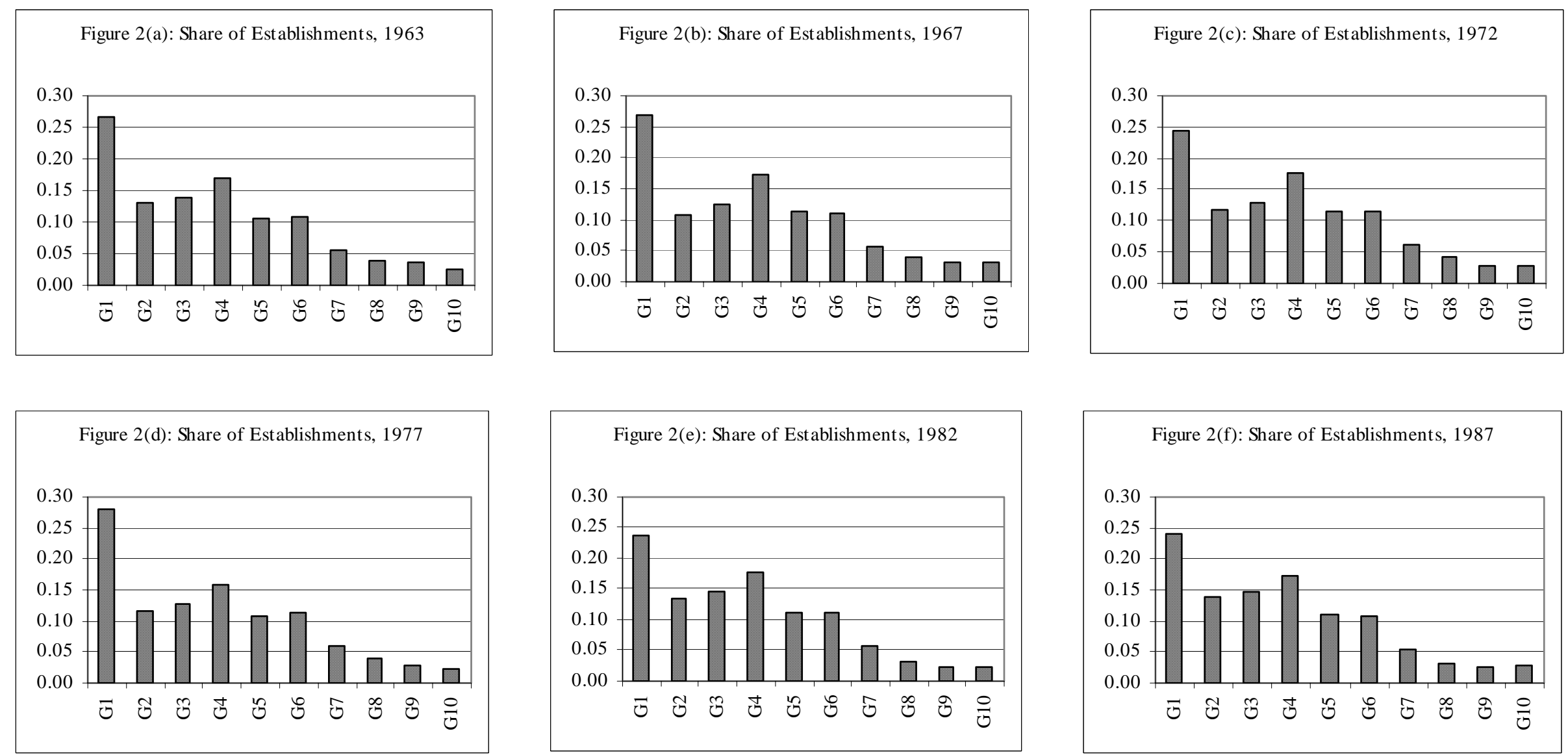

Figure 2(g): Share of Establishments, 1992

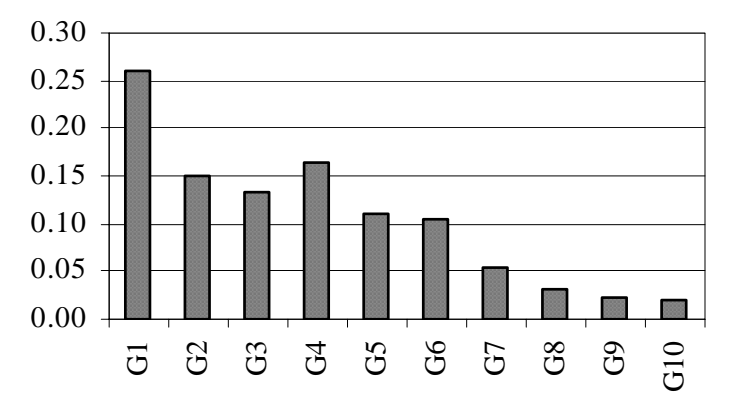

Notes for Figures 2(a)-2(g): The establishment size groups correspond to the following number of employees (in parentheses). G1 (1-4); G2 (5-9); G3 (10-19); G4 (20-49); G5 (50-99); G6 (100-249); G7 (250-499); G8 (500-999); G9 (1,000-2,499); and G10 (2,500 or more). The vertical axis indicates the share of the number of establishments for that group in the industry total. 